Article

\title{
Local Perceptions of Climate Change and Adaptation Responses from Two Mountain Regions in Tanzania
}

\author{
Kaiza R. Kaganzi ${ }^{1}{ }^{(1)}$, Aida Cuni-Sanchez ${ }^{2,3}$, Fatuma Mcharazo ${ }^{4}$, Emanuel H. Martin ${ }^{5}{ }^{\circledR}$, Robert A. Marchant ${ }^{2}(\mathbb{D}$ \\ and Jessica P. R. Thorn $2,6, *$ (D) \\ 1 Department of Wildlife Conservation and Political Ecology, School for International Training World Learning, \\ Arusha P.O. Box 6007, Tanzania; kaiza.kaganzi@sit.edu \\ 2 Department of Environment and Geography, York Institute of Tropical Ecosystems, University of York, \\ 290 Wentworth Way, Heslington, York YO10 5NG, UK; a.cunisanchez@york.ac.uk (A.C.-S.); \\ robert.marchant@york.ac.uk (R.A.M.) \\ 3 Department of International Environment and Development Studies (Noragric), Faculty of Landscape and \\ Society, Norwegian University of Life Sciences (NMBU), P.O. Box 5003, N-1432 Ås, Norway \\ 4 Tanzania National Parks, Arusha P.O. Box 3134, Tanzania; fettymcharazo@gmail.com \\ 5 Department of Wildlife Management, College of African Wildlife Management, Mweka, \\ Moshi P.O. Box 3031, Tanzania; emmanuel.martin2@mwekawildlife.ac.tz \\ 6 African Climate and Development Initiative, Geological Sciences Building, University of Cape Town, \\ Rondebosch, Cape Town 7700, South Africa \\ * Correspondence: jessica.thorn@york.ac.uk or jessicaprthorn@gmail.com
}

Citation: Kaganzi, K.R.;

Cuni-Sanchez, A.; Mcharazo, F.; Martin, E.H.; Marchant, R.A.; Thorn, J.P.R. Local Perceptions of Climate Change and Adaptation Responses from Two Mountain Regions in Tanzania. Land 2021, 10, 999. https:/ / doi.org/10.3390/land10100999

Academic Editor: Le Yu

Received: 21 July 2021

Accepted: 13 September 2021

Published: 23 September 2021

Publisher's Note: MDPI stays neutral with regard to jurisdictional claims in published maps and institutional affiliations.

Copyright: (c) 2021 by the authors. Licensee MDPI, Basel, Switzerland. This article is an open access article distributed under the terms and conditions of the Creative Commons Attribution (CC BY) license (https:// creativecommons.org/licenses/by/ $4.0 /)$.

\begin{abstract}
Mountain environments and communities are disproportionately impacted by climate change. Changes in temperature are greater than at lower elevations, which affect the height of the cloud base and local rainfall patterns. While our knowledge of the biophysical nature of climate change in East Africa has increased in the past few years, research on Indigenous farmers' perceptions and adaptation responses is still lacking, particularly in mountains regions. Semistructured interviews were administered to 300 farmers on Mount Kilimanjaro $(n=150)$ and the Udzungwa Mountains $(n=150)$ in Tanzania across gender and wealth groups. Respondents in both mountains reported not only changes in rainfall and temperature, corresponding with meteorological data, but also a greater incidence of fog, wind, frost, and hailstorms-with impacts on decreased crop yields and increased outbreaks of pests. The most common adaptation strategies used were improved crop varieties and inputs. Wealthier households diversified into horticulture or animal rearing, while poorer households of Hehe ethnicity diversified to labour and selling firewood. Despite being climate change literate and having access to radios, most respondents used Indigenous knowledge to decide on planting dates. Our findings highlight how context and culture are important when designing adaptation options and argue for greater involvement of local stakeholders in adaptation planning using a science-with-society approach. Place-based results offer generalisable insights that have application for other mountains in the Global South.
\end{abstract}

Keywords: farmer; Chagga; gender; East Africa; local knowledge; Kilimanjaro; Hehe; Udzungwa; wealth groups

\section{Introduction}

Mountains cover $30.5 \%$ of all land [1] and contain $23 \%$ of the Earth's total forest cover $[2,3]$. Mountains are home to $10 \%$ of the world's population-expected to grow to 736-844 million by 2050 [4]. Mountains provide benefits to almost half of the world's human population [3] and provide a range of ecosystem services and goods that are an important source of future agrobiodiversity, medicine, and associated poverty alleviation and sustainable development at local, regional, and international levels [5].

African mountains cover some 3 million $\mathrm{km}^{2}$-most of which are in the north-western, central, and eastern regions [6]. These mountains are critical water towers, supplying water 
and associated economic value to the surrounding lowlands. For instance, in East Africa, Mount Kilimanjaro provides water to the 3.8 million people who live within the Pangani Basin [7], which is used for hydroelectricity, irrigated agriculture, fishing, and domestic use, among other purposes [8]. The Drakensberg supplies most of the water to Southern Africa, while several countries in West Africa depend on water resources from the Fouta Djallon Highlands [6]. African mountains are centres of biodiversity and endemism due to their topographical variation and ruggedness [5]. Tropical forests in African mountains are also vitally important carbon stores [9]. Most African mountains are characterised by intensive land use, averaging between 33 and 500 persons $/ \mathrm{km}^{2}$, compared to 15 persons $/ \mathrm{km}^{2}$ in the lowlands [10]. This is particularly the case in tropical African mountains which have favourable environmental conditions for agriculture, in contrast to the generally much dryer surrounding lowlands [6]. For instance, the Ethiopian Highlands is home to 90\% of the population and $93 \%$ of the cultivated land in the country [10]. Moreover, African mountains have critical social-cultural value as Indigenous heritage landscapes [11,12], holding 40 of the UNESCO world heritage sites and biosphere reserves with associated tourism and recreation value [13]. For the purpose of this paper, we use the global mountain typology as defined by UNEP-WCMC (i.e., at a $1 \mathrm{~km}$ resolution, mountains as consisting on having a slope $>2^{\circ}$ or local elevation $\geq 300 \mathrm{~m}$, greater than $300 \mathrm{~m}$, including an isolated basin plateau $\geq 25 \mathrm{~km}$ [14]) - because it is the most robust definition of mountains of our study area in the Eastern Arc Mountains of Tanzania-covering an area of $48,000 \mathrm{~km}^{2}$ and with an upper limit of $2636 \mathrm{~m}$ asl [15].

African mountains and their communities are highly impacted by climate change and experience more rapid changes in temperature than lower elevations because the rate of warming is amplified with elevation [16]. Particularly important are warming effects such as a rising cloud base or reduced overall cloud incidence because clouds can be a critical source of water in mountain tropical forests [17]. Changes in climate are pronounced in East Africa, where high-resolution climate projections for Africa indicate the region is likely to experience increased mean annual temperatures and rainfall seasonality [18]. Fewer but heavier rainfall events adversely affect plant growth, while higher temperatures accelerate evapotranspiration [19]. For instance, recent droughts, floods, and delays of rains have led to crop damages, failure, and chronic food shortages [20,21].

Two iconic mountains impacted by climate change in Tanzania are Mount Kilimanjaro and the Udzungwa Mountains. The latter is located in the globally recognised Eastern Afromontane biodiversity hotspot [22-25]. The glacier that lines the volcanic crater of Mount Kilimanjaro has shrunk and could disappear by 2033, with impacts on water availability, seasonality, amount of runoff, and quality due to the release of heavy metals including mercury and other legacy contaminants currently stored in the glacier [7]. In the Udzungwa Mountains, climate change has negatively impacted the reproductive fitness of plant and animal species, leading to upslope migration of species and changes in the structures of freshwater and foraging communities-with knock-on effects on predatorprey relations [4].

In the face of climate change, agricultural and pastoral communities are adapting to changes. However, people's adaptive capacity to deal with these pressures is often compromised in the mountains due to remoteness and economic marginalisation coupled with inadequate extension services, poorly developed infrastructure, and high dependence on natural resources for water, energy, and food requirements [26]. Meanwhile, in many African mountains, as the human population has grown, land has become scarcer, deforestation has intensified, and soil fertility has declined-resulting in severe land degradation, land use conflicts, and declining productivity [10]. Habitat areas are shrinking, increasingly fragmented and overharvested for building material, fuel, and food [27], while species are threatened with extinction [28].

A growing body of literature in the last decade recognises the importance of local perceptions of climate change impacts on social-ecological systems, particularly in meteorological data-scarce areas [29-32]. Another body of literature evidences the synergistic 
mitigation and adaptation co-benefits of nature-based solutions in agricultural landscapes while counteracting ecological degradation and biodiversity [33]. Scholars argue that local communities' knowledge and worldviews, including 370 million Indigenous people worldwide [34], are critical to understanding, evaluating, and developing more effective, locally tailored adaptation options $[29,30]$. The necessity of diverse knowledge systems in climate change research-particularly related to past, present and future change in the face of uncertainty - has been established in the fifth assessment report of the Intergovernmental Panel on Climate Change (IPCC) [31,32]. Given this increasing recognition of the value of Indigenous knowledge, the IPCC has dedicated a chapter in the AR7 to capture societal perspectives on climate change around the world [35-38].

However, the historical and contextual complexities underpinning Indigenous people's knowledge, experiences, and impacts on livelihoods of climate change is largely overlooked, and the IPCC has been late to appreciate the value of these insights [39]. The existing literature on farmers perceptions of climate change shows that climatic change risks can be mediated through demographic factors, such as assets, gender, access to information and affiliation to cooperatives, and farmland characteristics, such as elevation, irrigation availability, and agricultural services [39,40]. However, relatively few studies have documented changes in African mountain regions and ensuing adaptive strategies [41,42]. In this paper, we use 'adaptive strategies' to refer to (i) strategies that evolved to manage climate shocks impacts ex-post (sometimes called 'coping strategies') and (ii) strategies which evolved to reduce overall vulnerability to climate shocks (sometimes called 'true adaptive strategies'). While there are multiple ways of categorising adaptation $[43,44]$ we do not differentiate between both types as some strategies which start as ex-post interventions in exceptional years can become 'truly' adaptation strategies for households or whole communities over time [45]. It could be argued that some 'adaptive strategies' mentioned here are related to other non-climatic stresses, as we mention in the Discussion Section 4.

Comparing the cases of Mount Kilimanjaro and the Udzungwa Mountains in Tanzania, this study aims to better understand the perceived changes, impacts, and adaptation responses of farmers in East African mountains. Objectives are to: (1) identify observed climate change and their impacts on streamflow, landslides, soil erosion, agricultural production, and human and livestock health; (2) evidence local farmers' adaptation strategies; (3) investigate different adaptation responses according to farmer characteristics of wealth and gender; and (4) understand how other factors such as climate change literacy, membership in farmers' associations, or labour availability support or hinder adaptation. Due to the predominance of agriculture-based livelihoods and historical sedentary settlements and culture, throughout the paper, we refer to our respondents as 'farmers', but we acknowledge that individuals may have multiple livelihood strategies.

Overall, in agreement with several previous studies, we call for greater integration of Indigenous knowledge and experience in international mechanisms and instruments [46]. Such instruments include not only the IPCC [39] but also the International Science-Panel on Biodiversity and Ecosystem Services, the UN Convention on Biological Diversity (CBD) articles $8(\mathrm{j})$ and 10(c), as well as the UNESCO and CBD Secretariat Joint Programme of work on the linkages between biological and cultural diversity. Greater efforts are needed to strengthen transdisciplinary engagements and dialogue between Indigenous people, extension agents, scientists, and policymakers to explore synergies and complementarities of different knowledge systems, create opportunities for innovation, experiment with novel methods to advance understandings, and co-produce knowledge [46]. A more integrative, participative approach that combines local perceptions with meteorological data and remote-sensing products [47] will likely improve the identification and selection of meaningful and more robust adaptation options. 


\section{Materials and Methods}

\subsection{Study Sites}

We studied two mountain systems in Tanzania because they represent a range of characteristics and wider social-ecological changes likely to be found in other mountain regions in sub-Saharan Africa. Both mountains are home to unique ethnic communities characterised by fast-growing populations, climate risks, transformations in agricultural practices, land and water systems, and shifts in regulatory contexts. Case studies thus offer broad regional coverage, which provides the rationale for generalising and scaling place-based results.

Mount Kilimanjaro (5895 $\mathrm{m}$ asl) has a bimodal rainfall regime with long rains (masika) starting from March to May, and short rains (vuli) from October to December. Rainfall and temperature change with increasing elevation. At about $1600 \mathrm{~m}$ asl, the mean annual rainfall is $2000 \mathrm{~mm}$ and temperature ranges between 15 and $30{ }^{\circ} \mathrm{C}$ [48]. Vegetation also changes with increasing elevation: from savannah (700-1000 $\mathrm{m}$ asl), submontane forest (1000-1800 m asl), montane forest (1800-3000 m asl) to alpine (above $3000 \mathrm{~m}$ asl) [49]. Most of the upper montane forest and alpine zones are now part of Mount Kilimanjaro National Park (declared in 1973) and UNESCO World Heritage Site (declared in 1987). As per Tanzania National Park's (TANAPA) policy, only non-consumptive activities are allowed within the park boundaries. However, given that local communities were previously allowed consumptive activities in the Kilimanjaro Forest Reserve (now part of the National Park), some women are permitted to collect dead stems for firewood within a half-mile strip next to the park boundary on the southern slopes (personal observation, 2020). Water that originates from the National Park is used not only for cultivation on the mountain slopes but also for irrigated rice, maize and tomato farms in the lowlands, flower cultivation around Arusha and hydropower plants at Nyumba ya Mungu and Hale and Pangani Falls [50].

The Chagga, of Bantu origin, are the largest ethnic group living on the southern slopes of Mount Kilimanjaro [49]. The Chagga home garden agroforestry system (intercropped trees with food cash crops) in the submontane forest zone, which dates to the seventeenth century, is considered one of the most productive areas of Tanzania [27,49]. As such, the Moshi District has a high population density-which in 2012 was 3409 people $/ \mathrm{km}^{2}$ compared to a national average of $67 \mathrm{~km}^{2}$ [51]. The traditional system uses gravity-fed irrigation canals (mifongo) in the dry season, where customary agreements determine where water is channelled to plots via furrows for specified durations. Farms at higher elevations use a traditional terracing technique (matuta).

Apart from green banana (plantain, the preferred stable food), coffee, and yams, which are cultivated throughout the year, farmers also grow maize and beans during the long rains. At higher elevations, farmers also cultivate beans and green leafy vegetables during the short rains. Apart from farming, the Chagga keep livestock (mostly cattle). Dairy is an important part of their diet, dung is used as manure, and cattle has important social value (e.g., used as a dowry) [44]. Livestock is mostly kept in stables, but a few people graze them outside. However, both the agroforestry system and irrigation systems are disappearing gradually due to market changes (e.g., low coffee prices, industrial logging of conifer plantations, tourism), climate change, and other environmental challenges (e.g., land and water scarcity) [27].

The Udzungwa Mountains ( $2576 \mathrm{~m}$ asl) has a bimodal rainfall regime in the wetter southern slopes, but the north-western part has a unimodal rainfall regime with most rainfall falling from March to May (c. $1400 \mathrm{~mm} / \mathrm{a}$ ) [45]. Here, vegetation also changes with increasing elevation from savannah to submontane and montane forest and grasslands above $2500 \mathrm{~m}$ asl. Most remaining montane forest is part of the Udzungwa Mountains National Park (declared in 1992). As per TANAPA's policy, since 2011, only non-consumptive activities are allowed in the park [52]. However, there is evidence of some illegal extraction of firewood, amongst other activities such as encroachment and poaching [53]. 
On the north-western slopes of the Udzungwa Mountains, the Hehe or Wahehe, of Bantu origin, are the dominant farmer ethnic group [54]. The Hehe also use the terracing system (matuta), gravity-fed irrigation canals (mitaro or mifereji), and a soil conservation technique using small ditches (mifereji).

During the long rains, farmers grow food crops of maize, beans, and millet, and cash crops such as Irish potatoes at higher elevations and onions and ground nuts at middle to lower elevations. Green banana is not commonly grown by the Hehe. Farmers often store cash crops in communal storage facilities for sale during April and May, when food supplies in cities are low and prices of such crops are high [45]. Apart from farming, some Hehe keep livestock (mostly goats and pigs) which are usually grazed in open areas and along roads. Yet, local farming livelihoods are increasingly challenging to sustain due to climate change, combined with ex situ land acquisition, commercial agricultural, tourism, and infrastructural investment in the Kilombero Valley [55].

\subsection{Data Collection}

We first conducted a literature review to assess the state of evidence of climate change impacts and adaptation in mountains, with a focus on mountains. Studies that were included in the review and were coded were qualitatively assessed for quality following [56], i.e., - the data collection methods were thoroughly explained, 2 - the sample size was well explained, 3-qualitative/quantitative analytical methods were clear and rational, 4 -results and conclusions were logically derived, and 5-confounding factors were considered and explained. In each study area, we used the same approach. First, exploratory focus group discussions were conducted with four to five elders in four villages: two villages located at higher and two at lower elevations (Figure 1). These discussions were used to design the semi-structured questionnaires and build rapport. We interviewed elders that have been living in each area for several decades and could potentially report a larger number of climatic changes and impacts. Then, we administered semi-structured questionnaires to 150 randomly selected household heads using purposive sampling (50\% male, 50\% female) in the same villages. Questionnaires addressed household characteristics and assets, perceived changes in climate and impacts on the biophysical environment in their lifetime, and adaptation strategies used to cope with or adapt to observed changes (Supplementary Material A). The questionnaire protocol followed the guidelines of the project Local Indicator of Climate Change Impacts ([56] Available online: https:/ / licci.eu/ (accessed on 12 September 2021)). Interviews were carried out in Swahili and were facilitated by two of the co-authors in November and December 2020. On Mount Kilimanjaro, all villages studied have gravity-fed irrigation canals (mifongo), but the number of households using irrigation varies, as well as community constructed reservoirs (ndiva) for domestic purposes in the wet season and water tanks and Moshi Urban Water Supply and Sanitation in the dry season. In only two of the villages studied (Foo and Kokirie), farmers use terracing (matuta). All four villages studied use gravity-fed irrigation canals (mitalo or mifireji), soil conservation technique (mifereji), and the terracing system (matuta).

\subsection{Data Analysis}

The percentage of respondents was the main unit of analysis for each mountain. First, we explored the main patterns and differences between communities. Second, we reported the effects of village elevation by pooling respondents into the four different villages sampled. Third, we explored the effects of gender by pooling respondents into two gender groups. Fourth, we explored the effects of wealth by pooling respondents into three groups (poor, average, rich). A wealth index was created from 10 asset indicators [46,57]. In each mountain, assets that were owned by $<25 \%$ of the households were weighted 0.25 greater than those more commonly found (Supplementary Material B). Following this, paired $t$-tests were used to assess significant differences between genders, while cross-tabulation tables and chi-square tests were used to determine significant relationships between wealth groups and adaptation strategies. We used wealth group as explanatory variable and 
adaptation strategies as response variables. We used a significance level of $p<0.05$. The Statistical Package for Social Science (SPSS) version 27 was used for all data analysis.

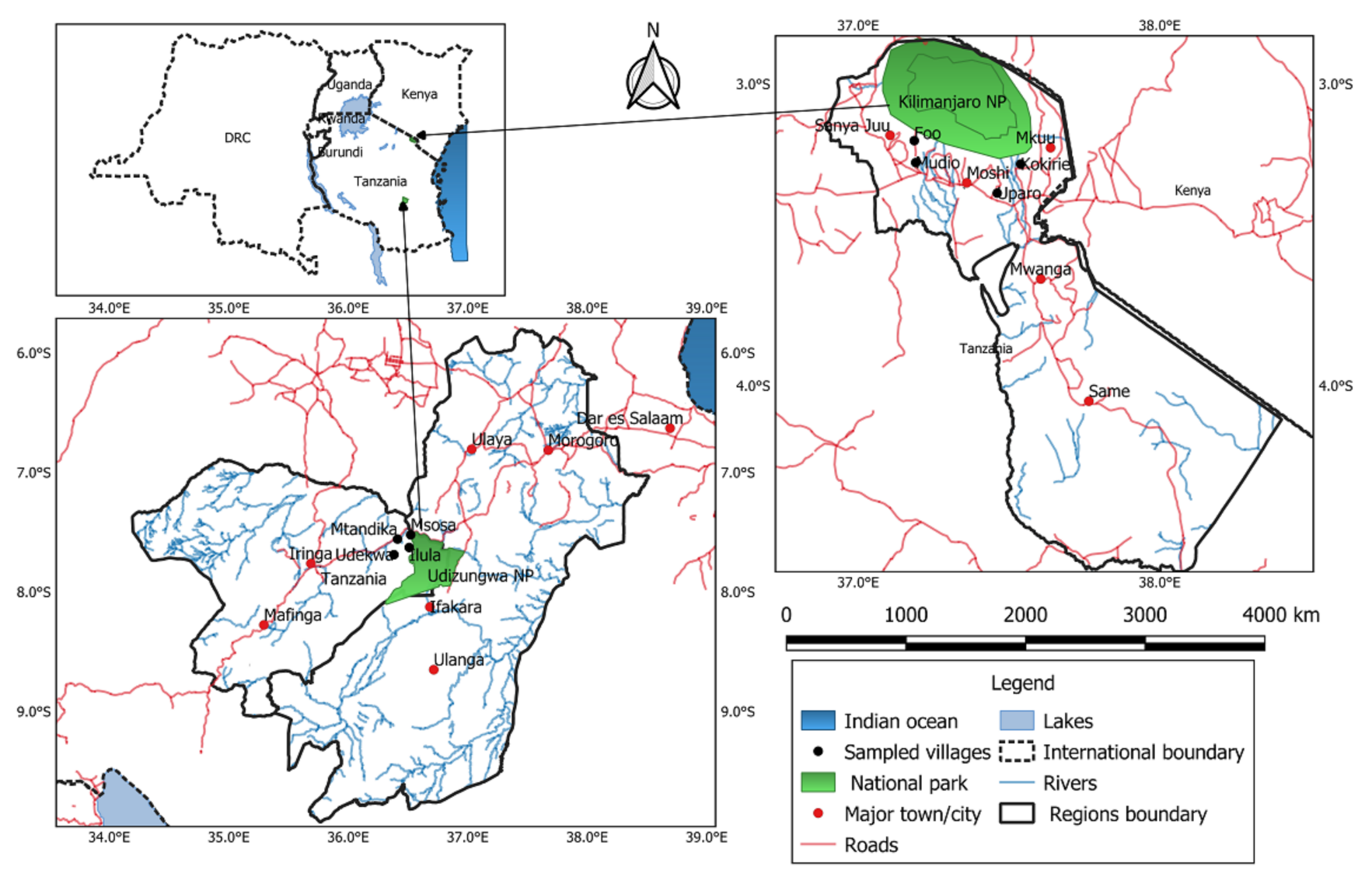

Figure 1. Map of Tanzania (top left inset) showing the locations of the two national parks. The sampled villages for Udzungwa are situated in the Rufiji River Basin, while sampled villages for Mount Kilimanjaro are situated in the Pangani River Basin. In each study site, four villages were sampled. Villages sampled in the Udzungwa Mountains were Udekwa (1013 m asl; $\left.7^{\circ} 41^{\prime} 14.64^{\prime \prime} \mathrm{S} 36^{\circ} 23^{\prime} 1.68^{\prime \prime} \mathrm{E}\right)$, Mtandika (570 m asl; $\left.7^{\circ} 33^{\prime} 19.08^{\prime \prime} \mathrm{S} 36^{\circ} 23^{\prime} 48.48^{\prime \prime} \mathrm{E}\right)$, Msosa (596 m asl; $7^{\circ} 32^{\prime} 31.56^{\prime \prime} \mathrm{S}$ $\left.36^{\circ} 30^{\prime} 7.56^{\prime \prime} \mathrm{E}\right)$, and Ilula (1370 m asl; $\left.7^{\circ} 37^{\prime} 34.32^{\prime \prime} \mathrm{S} 36^{\circ} 30^{\prime} 35.64^{\prime \prime} \mathrm{E}\right)$. Villages sampled in Mount Kiliminjaro were Foo (1694 m asl; $\left.3^{\circ} 11^{\prime} 27.96^{\prime \prime} \mathrm{S} 37^{\circ} 13^{\prime} 40.44^{\prime \prime} \mathrm{E}\right)$, Uparo (1426 m asl; $\left.3^{\circ} 21^{\prime} 34.92^{\prime \prime S} 37^{\circ} 27^{\prime} 41.04^{\prime \prime} \mathrm{E}\right)$, Kokirie Mamba (1630 m asl; $3^{\circ} 15^{\prime} 46.44^{\prime \prime} \mathrm{S}$

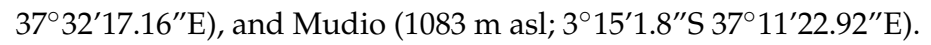

\section{Results}

\subsection{Climatic Changes and Impacts}

Most respondents ( $\geq 70 \%$ ) on both mountains reported increased temperatures during the dry and the rainy seasons and a reduction in the number of frost days (Figure 2). Most respondents $(\geq 70 \%)$ on both mountains also observed a reduction in the duration and amount of rainfall and fog during the long rains and an increase in dry spells and strong winds. Most respondents reported decreased stream flow and fewer hailstorms, and increased rain showers during the dry season. One main difference between the two sites were reports of increased extreme events, particularly floods and droughts: more respondents on the Udzungwa Mountains reported these compared to Mount Kilimanjaro (80\% vs. 30\%, respectively). However, more respondents on Mount Kilimanjaro reported an increased number of landslides ( $45 \%$ vs. $5 \%$ ). In the two high-elevation villages on Mount Kilimanjaro, respondents also noted that the amount and duration of the short rains had changed. This was described by a female leader in Foo as follows: 'Vuli (short rains) have become unreliable. Sometimes there is too little rain to grow crops, and sometimes these rains are so long that they end up destroying the crop'. 
Kili $\square$ Udz

Increased temperatures (dry season) Increased temperatures (rainy season) Reduced rainfall (long rains)

Late start long rains More dry spels (long rains) More showers (dry season) More extreme floods More extreme droughts Fewer foggy days Less frost Increased wind (rainy season) Fewer hail storms Reduced stream flow (rainy season) More landslides (rainy season) More soll erosion (rainy season)

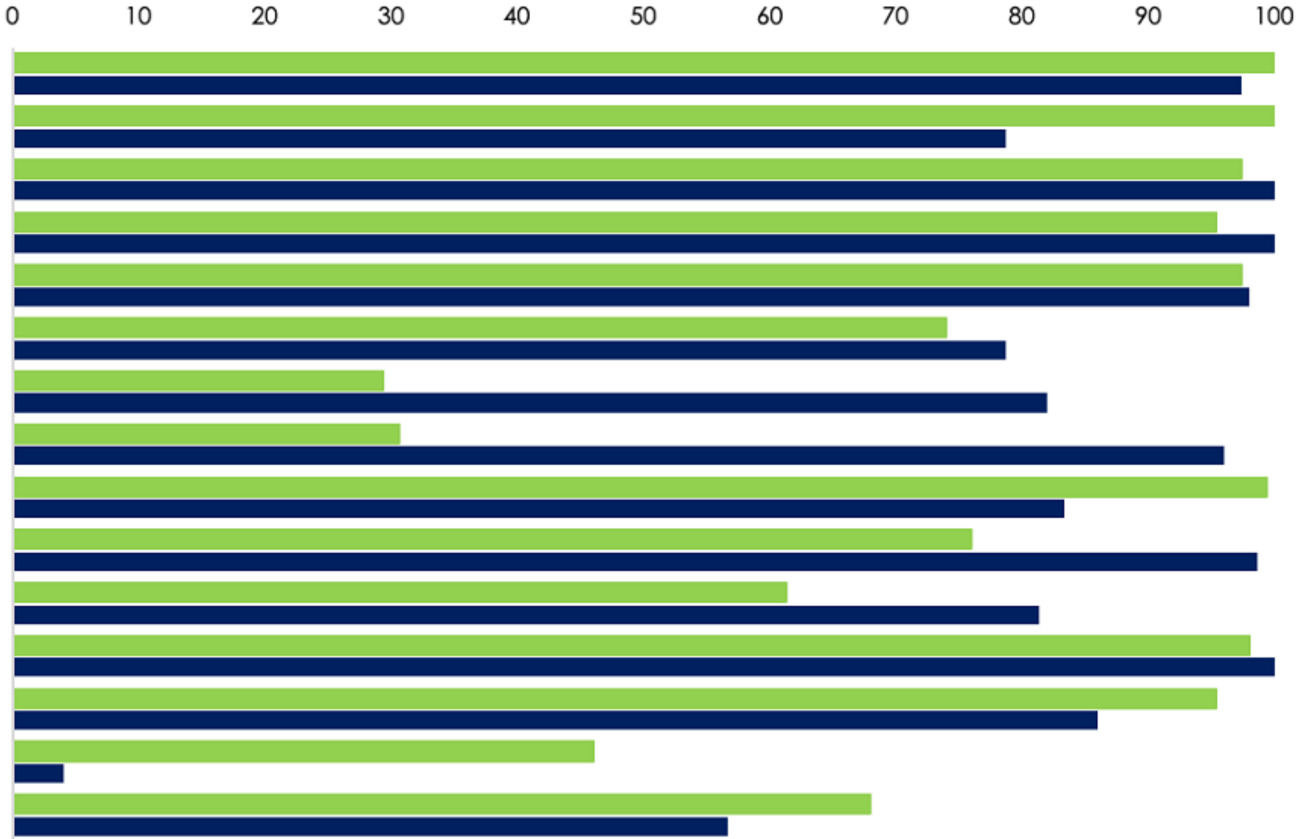

Figure 2. Observed changes in climate and impacts in the physical domain in terms of percentage of respondents in each mountain ( $n=150$ on Mount Kilimanjaro, $n=150$ on the Udzungwa Mountains). On the Udzungwa Mountains, long rains refer to the only rainy season found on the north-western slopes. We did not specifically ask every respondent on Mount Kilimanjaro about the short rains, so these are not included in Figure 2.

Within each mountain, few differences were observed between villages at different elevations. On Mount Kilimanjaro, the main differences were that fewer respondents in Mudio (the lowest-elevation village) reported increased rain showers during the dry season, while more respondents in Kokire Mamba reported more landslides. In the Udzungwa Mountains, more respondents in Udekwa reported increased soil erosion (Supplementary Material C).

Respondents in both mountains reported reduced crop yields and an increase in crop pests and diseases, but the percentage of respondents varied for the different crops, being greater for maize, beans, coffee, and green banana (Figure 3). On Mount Kilimanjaro, respondents reported the most harmful crop pests as including viwavi jeshi (fall armyworm), which feeds on the stem and leaves of maize; kishori or mnyauko (fusarium wilt of banana), which dries the leaves of green banana and coffee; kimamba (green scale coccus viridis), which coils green leaves for beans and coffee; and kimatira and uwiwi (coffee berry borer), which attacks the fleshy berry surrounding the coffee kernel. On the Udzungwa Mountains, the most harmful pests were viwavi jeshi (fall armyworm) and michilizi (yellow striped virus), which affect maize by stunting the growth of panicles and flowers or causing the plant to be sterile; fangasi (rust), which, in beans, results in stunted growth; and utitiri mwekundu (red spider mites) and vipekecha majani (leaf miner), which, for onions, sucks the plant sap, grinds the leaves, and feeds on the plant tissue. Farmers noticed changes in pest incidence with increased temperature, which created favourable environments and changed ecological niches. For instance, farmers observed wadudu chawa (thrips) increased in abundance on onion leaves when there is little rainfall and high temperatures. Respondents on both mountains reported reduced milk production and an increase in cattle diseases, but more respondents reported these on Mount Kilimanjaro-probably as a larger percentage of respondents in this mountain own cattle, and milk production is an important component of the diet and culture of the Chagga. Surrounding the Udzungwa Mountains, more respondents reported increased diseases amongst goats. In both mountains, respondents said human health was adversely affected by climate change impacts (Figure 3). 


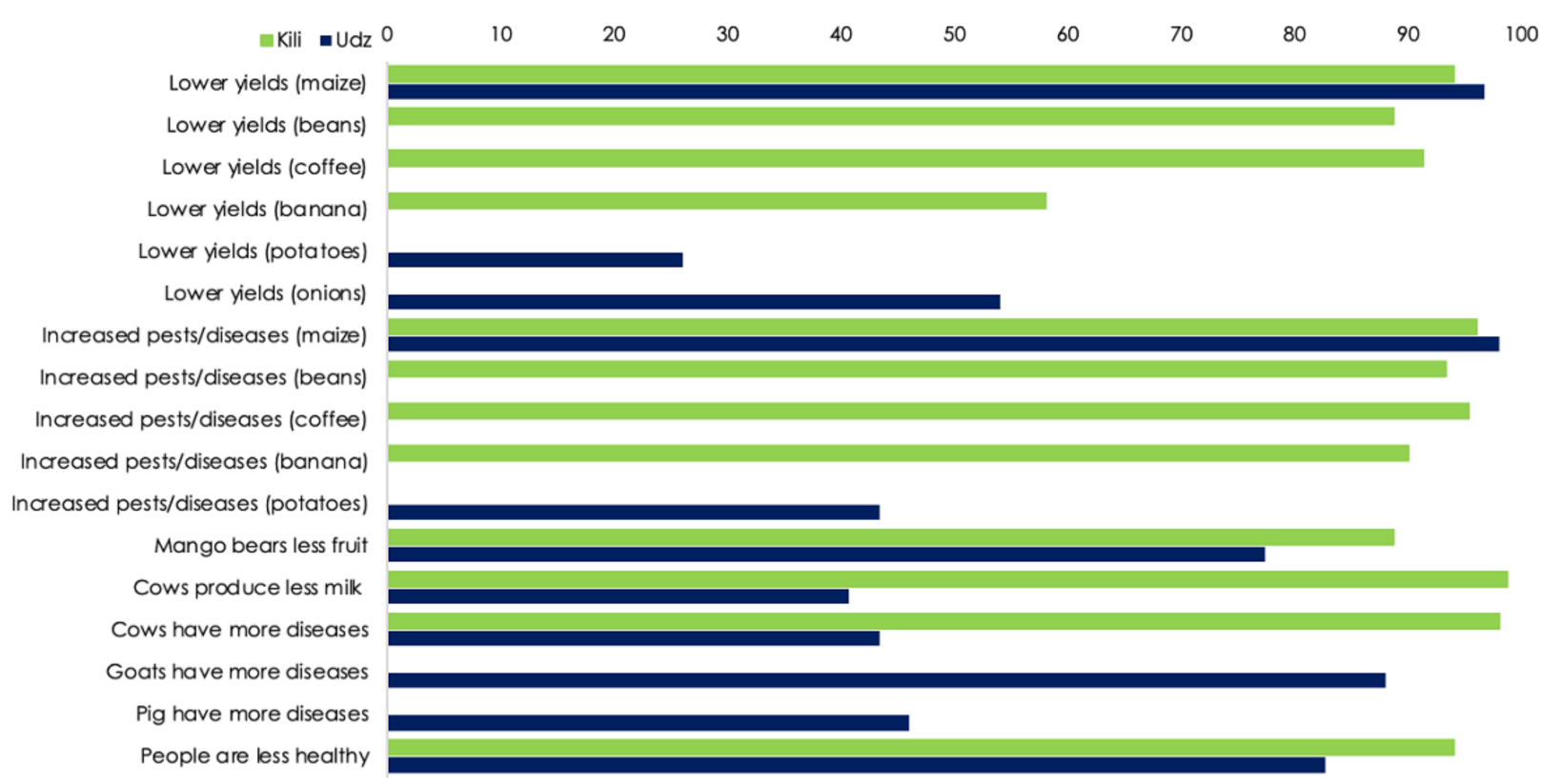

Figure 3. Observed impacts in the biological domain regarding percent of respondents in each mountain ( $n=150$ on Mount Kilimanjaro, $n=150$ on the Udzungwa Mountains). Coffee and green bananas are not cultivated in our study area of Udzungwa Mountains. Although Irish potatoes, onions, pigs, and goats are grown by some farmers on Mount Kilimanjaro, we excluded these in the questionnaire on Mount Kilimanjaro as they are not widespread.

On Mount Kilimanjaro, the main differences across villages were that fewer respondents in Foo (the highest elevation village) reported decreased yields for green bananas (Supplementary Material C). On the Udzungwa Mountains, only respondents at high elevation villages (Ilula and Udekwa) reported reduced yields for Irish potatoes. Lower elevation villages were not involved in such farming activities.

\subsection{Adaptation Strategies}

The main adaptation strategies in both mountains were modifying farming or animal rearing. To adapt to climate changes, most farmers shifted to using improved crop varieties (mostly banana, maize, and beans) - preferring traits to improve disease, pest and drought resistance, early maturing, and high yield, depending on the context (Figures 3 and 4). This could be in part because in the past decade, agricultural extension programmes and research institutions have introduced several improved varieties of seeds. Respondents also mentioned increased use of soil conservation techniques, chemical fertilisers, and pesticides. Changing farm location, increasing farm size, and irrigation uptake were mentioned by more respondents on the Udzungwa Mountains than on Mount Kilimanjaro-where there is high population density. However, respondents highlighted that agrochemical use could lead to air and water pollution, while irrigation can lead to soil salinisation. Only around the Udzungwa Mountains did farmers cite changing crop species (e.g., from maize to drought-resistant millet), although there is some resistance due the shortage of seeds, food preferences, and the fact that maize has historically been planted. Notably, farmers on Mount Kilimanjaro reported sowing seeds later in the planting season, while around the Udzungwa Mountains, farmers sowed them earlier. In both study areas, farmers sowed seeds twice in one season when needed. Interestingly, most study participants mentioned changing planting dates. 


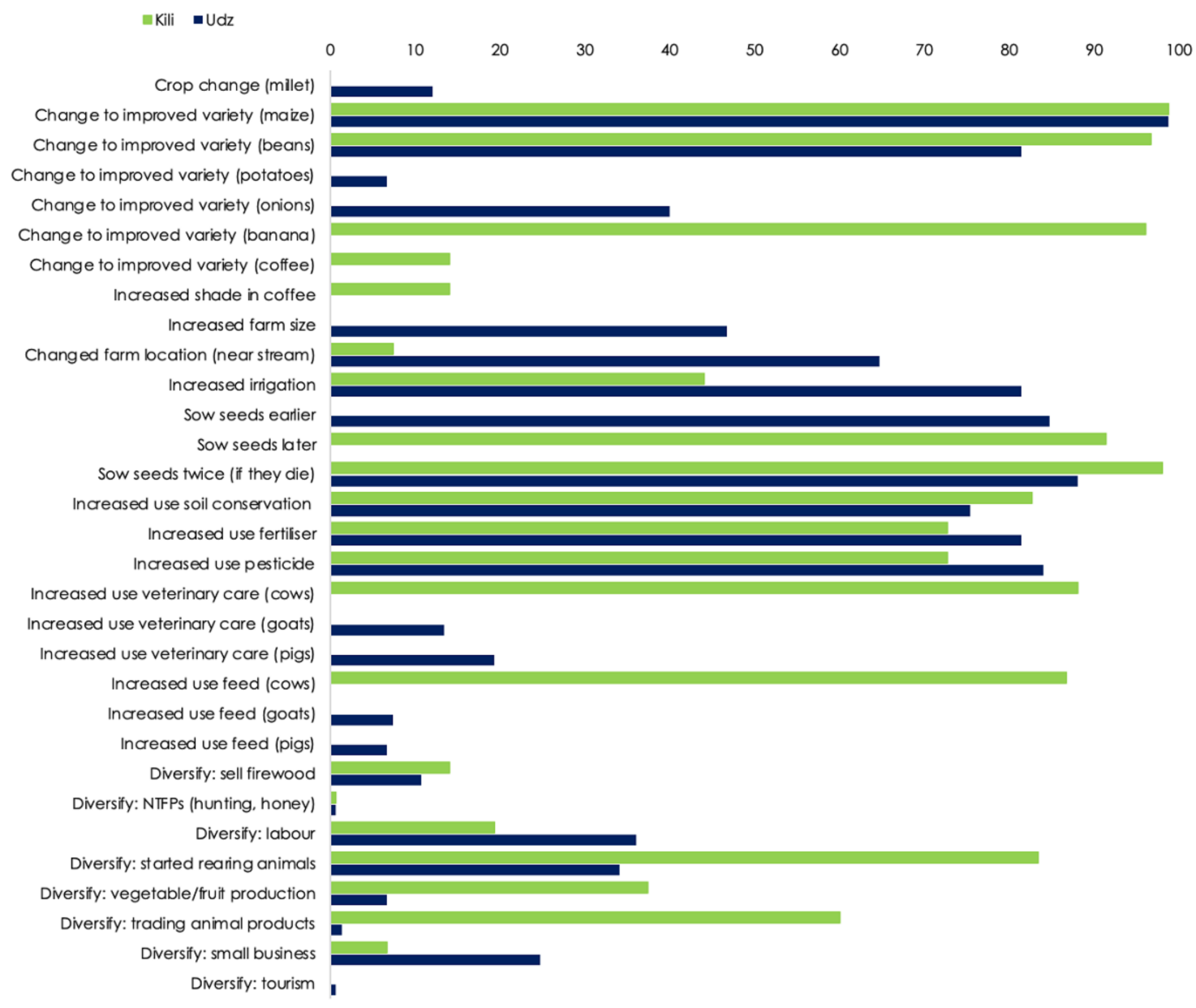

Figure 4. Adaptation strategies used by study respondents (\%) ( $n=150$ on Mount Kilimanjaro, $n=150$ on the Udzungwa Mountains). Coffee and bananas are not cultivated in our study area of the Udzungwa Mountains. Although Irish potatoes, onions, pigs, and goats are grown by some farms on Mount Kilimanjaro, we excluded these in the questionnaire on Mount Kilimanjaro as they are not widespread. NTFPs: Non-timber forest products.

On Mount Kilimanjaro, most farmers reported increased use of veterinary care and supplementary feed for cattle, while on the Udzungwa Mountains, a few respondents mentioned an increased use of veterinary care for goats and pigs. On both mountains, diversifying livelihoods was also cited, with increasing animal rearing or vegetable production being the most cited on Mount Kilimanjaro and casual labour employment or animal rearing being the most cited on the Udzungwa Mountains. In both regions, some respondents turned into firewood collection and trade, and some started small businesses (Figure 4). Across mountains, less than $30 \%$ use information from extension officers or radio $(<30 \%)$ on when to sow seeds- even though most respondents in both mountains have a radio (Supplementary Material B). Instead, most farmers still used personal observations (e.g., observing when certain plants bloom before the long rains start or when certain birds sing).

Some differences were observed on Mount Kilimanjaro regarding village elevation. For example, fewer people in Uparu reported increased use of pesticides or fertilisers, and more respondents in Mudio (the lowest-elevation village) reported increased vegetable and fruit production and the trade of animal products. In the Udzungwa Mountains, only respondents in Ilula reported using improved varieties of Irish potatoes. In addition, increased use of pesticides and fertilisers was lower in Udekwa, and more respondents in Ilula reported increased use of veterinary care for pigs (Supplementary Material C). 


\subsection{Differentiated Adaptation Responses by Wealth and Gender}

On Mount Kilimanjaro, wealth had a significant effect on five adaptation strategies. Wealthier households had a significantly higher adoption of the following adaptations: increased irrigation (63.3\%), increased use of fertilisers (91.8\%), increased use of pesticides $(89.8 \%)$, increased vegetable farming $(63.3 \%)$, and trading animal products $(77.6 \%)$ (Table 1$)$. Around the Udzungwa Mountains, wealth had a significant effect on nine adaptation strategies, including four of those also affected by wealth in Mount Kilimanjaro (Table 2). Poorer households had a significantly higher adoption of the following adaptations: diversify to sell firewood (18.8\%), diversify to labour $(46.9 \%)$ and diversify to rearing animals $(20.3 \%)$. Interestingly, a major difference between the adaptations of the Hehe compared to the Chagga was that a greater number of poor than wealthy households had diversified to labour $(46.9 \%$ vs. $10.7 \%)$ and selling firewood (18.8\% vs. $7.1 \%)$. Gender was not significantly associated with adaptation responses (see results in Supplementary Material D).

Table 1. Adaptive strategies used by each wealth group on Mount Kilimanjaro (\% respondents within wealth group).

* Significant differences across wealth groups at $p>0.05$, using cross-tabulation tables and chi-square tests.

\begin{tabular}{|c|c|c|c|}
\hline Adaptive Strategies & Rich (\%) & Average (\%) & Poor (\%) \\
\hline Change to improved variety (maize) & 100.0 & 97.6 & 100.0 \\
\hline Change to improved variety (beans) & 98.0 & 97.6 & 94.7 \\
\hline Change to improved variety (green banana) & 91.8 & 97.6 & 100.0 \\
\hline Change to improved variety (coffee) & 20.4 & 12.2 & 5.3 \\
\hline Increased shade in coffee & 20.4 & 11.0 & 10.5 \\
\hline Changed farm location (near stream) & 18.4 & 1.2 & 5.3 \\
\hline Increased irrigation & $63.3 *$ & $41.5 *$ & $5.3 *$ \\
\hline Sow seeds later & 95.9 & 87.8 & 94.7 \\
\hline Sow seeds twice (if they die) & 98.0 & 97.6 & 100.0 \\
\hline Increased use of soil conservation & 89.8 & 74.4 & 100.0 \\
\hline Increased use of fertiliser & $91.8 *$ & $68.3 *$ & $42.1 *$ \\
\hline Increased use of pesticide & $89.8 *$ & $70.7 *$ & $36.8 *$ \\
\hline Increased use of veterinary care (cows) & 91.8 & 89.0 & 73.7 \\
\hline Increased use of feed (cows) & 91.8 & 86.6 & 73.7 \\
\hline Diversify: sell firewood & 22.4 & 9.8 & 10.5 \\
\hline Diversify: labour & 20.4 & 22.0 & 5.3 \\
\hline Diversify: started rearing animals & 85.7 & 85.4 & 68.4 \\
\hline Diversify: vegetable/fruit production & $63.3 *$ & $29.3 *$ & $5.3 *$ \\
\hline Diversify: trading animal products & $77.6 *$ & $53.7 *$ & $42.1 *$ \\
\hline
\end{tabular}

Table 2. Adaptive strategies used by each wealth group on Udzungwa Mountains (\% respondents within wealth group).

* Significant differences across wealth groups at $p>0.05$, using cross-tabulation tables and chi-square tests.

\begin{tabular}{|c|c|c|c|}
\hline Adaptive Strategies & Rich (\%) & Average (\%) & Poor $(\%)$ \\
\hline Crop change (millet) & 10.7 & 15.5 & 9.4 \\
\hline Change to improved variety (maize) & 100.0 & 100.0 & 96.9 \\
\hline Change to improved variety (beans) & 89.3 & 86.2 & 73.4 \\
\hline Change to improved variety (potatoes) & 14.3 & 8.6 & 1.6 \\
\hline Change to improved variety (onions) & $78.6^{*}$ & $36.2 *$ & $26.6 *$ \\
\hline Increased farm size & 57.1 & 46.6 & 42.2 \\
\hline Changed farm location (near stream) & $89.3 *$ & $63.8 *$ & $54.7 *$ \\
\hline Increased irrigation & $96.4 *$ & $82.8 *$ & 73.4 * \\
\hline Sow seeds later & 71.4 & 84.5 & 90.6 \\
\hline Sow seeds twice (if they die) & 92.9 & 89.7 & 84.4 \\
\hline Increased use of soil conservation & $89.3 *$ & $79.3 *$ & $65.6 *$ \\
\hline Increased use of fertiliser & $100.0 *$ & $79.3 *$ & $75.0 *$ \\
\hline Increased use of pesticide & $100.0 *$ & $82.8 *$ & $78.1 *$ \\
\hline Increased use of veterinary care (goats) & 21.4 & 15.5 & 7.8 \\
\hline Increased use of veterinary care (pigs) & 17.9 & 27.6 & 12.5 \\
\hline Diversify: sell firewood & $7.1 *$ & $3.4 *$ & $18.8 *$ \\
\hline Diversify: labour & $10.7 *$ & $36.2 *$ & $46.9 *$ \\
\hline Diversify: started rearing animals & 17.9 * & $56.9 *$ & $20.3 *$ \\
\hline Diversify: vegetable/fruit production & 10.7 & 1.7 & 0.0 \\
\hline
\end{tabular}




\subsection{Other Factors Supporting or Hindering the Adoption of Adaptation Strategies}

In terms of factors supporting adaptation, farmers associations help provide loans to buy food or seeds or offer financial help to diversify income or start a small business. Approximately $51 \%$ of farmers are members of farmer organisations (i.e., $56 \%$ on Mount Kilimanjaro and $46 \%$ on Udzungwa). These are mostly women's or loan associations. When asking about the use of climate information, farmers indicate they access information from radio, television, or church. Most male and female Chagga and Hehe respondents had some schooling, more Chagga than Hehe listen to a radio on a daily basis, while $99.3 \%$ and $98.6 \%$, respectively, understood the term 'anthropogenic climate change'. However, respondents explained that they do not trust the predictions from meteorological agencies because they feel the information given is not useful, which was described by a leader in a Uparo village in Kilimanjaro as due to the fact that the 'Two-day predictions from the radio are too short notice to prepare the fields'. This hinders the use of climate information to inform land management decision making.

Factors that hinder adaptation relate predominantly to land tenure and ownership rights, labour availability, high initial investment costs for adaptation, and limited technical skills for new practices. Food preferences further influence decisions to diversify crops. For instance, some Chagga avoid cassava and sweet potato because these crops are perceived as a 'hunger food'.

\section{Discussion}

\subsection{Climatic Changes and Impacts}

Our study provides evidence of how Indigenous communities can provide insights on the climatic changes already observed on mountains for a wide range of climate variables beyond rainfall and temperature (e.g., fog, rain showers, hailstorms), as shown by other studies [37-39]. If fog is expected to change considerably due to predicted increased temperatures and raising cloud base in African mountains $[17,58]$ and few meteorological stations record such variables, local peoples' perceptions of change could be used to better understand non-precipitating changes in moistures impacts on crop and fodder production.

In general, the climatic changes reported by farmers in this study agree with previous studies on climate change perceptions in Tanzania's mountains [27,45,48,59-63], but we investigated more variables than previous studies (Table 3 and references therein). For instance, increased temperatures, reduced duration and amount of rainfall, and more dry spells during the long rains were reported by previous studies on Kilimanjaro, Pare, Uluguru, Usambara, and Udzungwa mountains and the Southern Highlands. However, in the Udzungwa Mountains, the early onset of the rainy season was noted instead of a later onset of rainfall - which we report here. Decreased stream flow was previously reported in both mountains $[27,45,59,61,64,65]$. An increase in extreme droughts was not identified in previous studies on Mount Kilimanjaro, although it was cited in the Pare and Udzungwa Mountains. An increase in wind strength during the rainy season was previously mentioned in the Pare Mountains [64], but not on Mount Kilimanjaro and the Udzungwa Mountains. While our study participants in both mountains reported important changes in fog, only one previous study recorded this change in the East Usambaras [66]. Some of the differences between this and previous studies in the same mountains could be related to local topography or climatic conditions (e.g., villages in ridges being more exposed to wind) [67]. The fact that some previous studies were conducted a decade ago might also explain differences across our and previous studies-if some phenomena have intensified in recent years.

As highlighted by [30,68], tapping into the detail of the climatic changes perceived by local communities allows researchers and practitioners to better understand the nuances of climate impacts on farmer livelihoods and ensuing locally acceptable adaptation decisions. For example, both dry spells during the rainy season or showers during the dry season can negatively affect maize yields, but fog can be a source of moisture for seed germination [58]. 
The perceived changes in rainfall and temperatures reported by farmers agree with available meteorological data. On Mount Kilimanjaro, rainfall measurements at three different elevations indicate a significant reduction in annual rainfall up to 2004 [68]. However, a recent re-analysis for Kilimanjaro airport showed no significant trend for the period 1973-2013, except for increased rainfall in March but reduced rainfall in April [69], which was also noted between 2001 and 2019 [59]. Respondents suggested this may be due to the late onset of the long rains. Differences in perceived and observed change could also be related to the fact that Kilimanjaro airport is located between 30 and $80 \mathrm{~km}$ from the villages sampled-further emphasising the need to capture local perceptions, particularly on mountains where the environment vary significantly over short distances. Available meteorological data also indicate increased temperatures [69,70], in agreement with farmer's perceptions. We did not have access to meteorological data from the Udzungwa Mountains as the only meteorological station in the region is located at much lower elevations.

Regarding impacts in the biophysical domain, only some of the impacts mentioned by our study participants have been reported by other studies. Surprisingly, lower yields for green banana and beans were not mentioned in previous studies on Mount Kilimanjaro, although the latter was reported in the Pare Mountains and [71] reported maize pests in Kilimanjaro. Several Chagga respondents highlighted that organisations should help ensure the productive yield of their preferred staple crop (green banana), which could be considered a cultural keystone species [72], as most instead focus on coffee.

Regarding livestock, previous studies in Tanzania's mountains did not report decreased milk or increased diseases, but these were reported from other locations in Tanzania [73]. A study in the mountains in northern Kenya [58] mentioned reduced fodder availability due to increasing droughts and related weak health of animals.

Previous studies on Mount Kilimanjaro did not mention reduced human health due to climate changes, but this was noted in the Udzungwa Mountains. Reasons related to increasing temperatures influencing the prevalence of waterborne diseases (cholera, typhoid, dysentery, malaria, and amoebic diseases) where there is limited potable water, as suggested by [74] for the Kilombero district and reported by [43]. Non-climatic factors could also affect health, such as reduced stream flow, upstream pollution, and river farming leading to deposition of agrochemicals in watercourses. We were unable to investigate the nuances of reduced human health, and thus future work is clearly needed in this area that combines medical data with insights from communities [75,76]. 
Table 3. Climatic changes and impacts as reported by other studies on farmers' perceptions in Tanzania's mountains. (H: Highlands). ${ }^{1}[63] ;{ }^{2}[48] ;{ }^{3}[27] ;{ }^{4}[59] ;{ }^{5}[45] ;{ }^{6}[60] ;{ }^{7}[61] ;{ }^{8}[62] ;$

${ }^{9}[42] ;{ }^{10}[60] ;{ }^{11}[60] ;{ }^{12}[4] ;{ }^{13}[76] ;{ }^{14}[77] ;{ }^{15}[65] ;{ }^{16}[32] ;{ }^{17}[66]$.

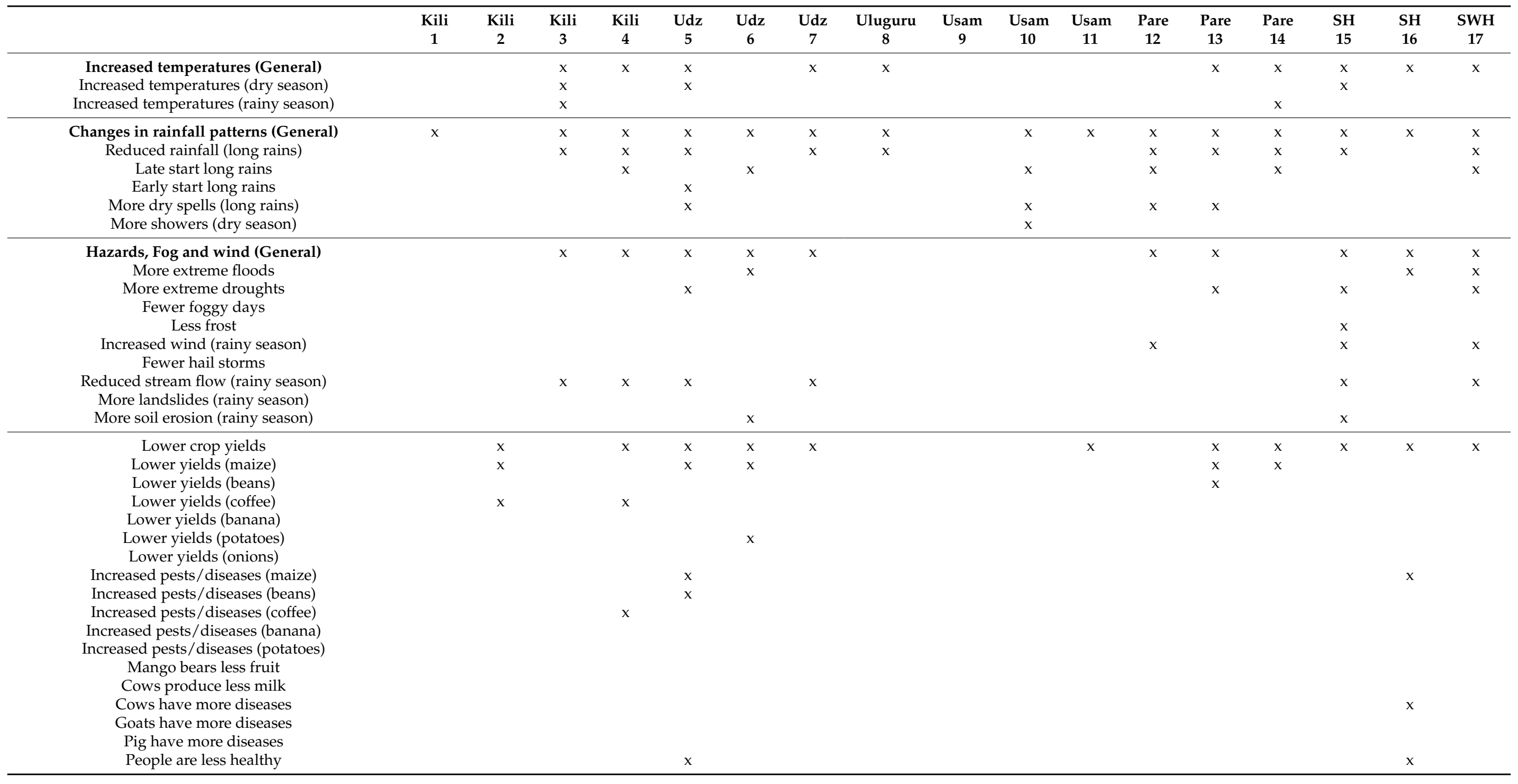




\subsection{Adaptation Strategies}

Previous work on Tanzanian farmers' adaptation to climate change (Table 4) highlighted that a combination of strategies is often used, including, inter alia, agricultural extensification, intensification, livelihood diversification, pooling of resources and labour, and migration [78]. On Mount Kilimanjaro, farmers changed the crop they planted. This is similar to studies in drier parts of Tanzania, where farmers increase the cultivation of sweet potatoes and cassava in dry years (or following a 'bad' year for maize) [20,78]. Coffee farmers grow shade trees to adapt to heat stress, a strategy previously undocumented for Mount Kilimanjaro but recorded in the Jimma Mountains, Ethiopia [77]. In the Usambara Mountains, increased use of agroforestry was cited for non-coffee crops [42], but this was not mentioned by our study participants. Others switched to vegetable or fruit production. Agricultural extensification was only used by some respondents surrounding the Udzungwa Mountains, but not in the southern slopes of Mount Kilimanjaro. This may be in part due to higher land scarcity coupled with high population density in the latter site.

Farmers also changed animal rearing practices as they intensified the use of veterinary care. This was previously undocumented for Mount Kilimanjaro but was mentioned in the mountains of northern Kenya [58].

Although most adaptation strategies focused on modifying farming practices, livelihood diversification was also cited, i.e., selling firewood, establishing a small business, and providing labour-most of which had been mentioned in previous studies. The sustainability of these strategies requires further investigation, especially collecting and selling firewood. Several other authors have highlighted the increased degradation of forests in the Eastern Arc Mountains (which includes the Udzungwa Mountains) [79]. Remarkably, very few households mentioned harvesting or trading non-timber forest products, which is different from previous studies in other African mountains [52]. This may be attributed to: the fact that we studied communities whose predominant livelihood activity is agriculture, fear of reporting illegal actions, changes in law reinforcement in the national parks, growing electrification, the fact that national park authorities in 2019 launched a household tree planting initiative to overcome firewood availability [80], or because the agroforestry farming system in Kilimanjaro has lowered firewood demand among villagers. In contrast to other studies across sub-Saharan Africa [81-83], we did not find evidence of migration due to climate change. Nevertheless, people are likely to migrate for other reasons such as education, lifestyle aspirations, and seasonal or permanent employment.

\subsection{Differentiated Adaptation Responses by Wealth and Gender}

We found that wealthier households used more inputs (e.g., irrigation, fertilisers, pesticides) and diversified commodities produced (e.g., horticulture, trading animal products), similar to other studies (e.g., [31]). However, we found one difference to previous work: in Udzungwa, poorer households used labour as diversification, but not in Mount Kilimanjaro. Most Chagga have invested in educating their children-some of which now work in urban areas and send remittances-which could explain why some do not engage in labour. Notably, even poor Chagga households are relatively wealthier than poor Hehe households in terms of assets-for example, owning a radio. 


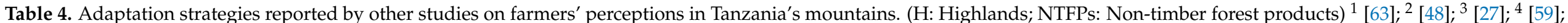

${ }^{5}$ [45]; ${ }^{6}$ [60]; ${ }^{7}$ [61]; ${ }^{8}[84] ;{ }^{9}[42] ;{ }^{10}[60] ;{ }^{11}[60] ;{ }^{12}$ [35]; ${ }^{13}$ [76]; ${ }^{14}[78] ;{ }^{15}[28] ;{ }^{16}$ [85]; ${ }^{17}$ [66].

\begin{tabular}{|c|c|c|c|c|c|c|c|c|c|c|c|c|c|c|c|c|c|}
\hline Mountain & $\begin{array}{c}\text { Kili } \\
1\end{array}$ & $\begin{array}{c}\text { Kili } \\
2\end{array}$ & $\begin{array}{c}\text { Kili } \\
3\end{array}$ & $\begin{array}{c}\text { Kili } \\
4\end{array}$ & $\begin{array}{c}\mathrm{Udz} \\
5\end{array}$ & $\begin{array}{c}\mathrm{Udz} \\
6\end{array}$ & $\begin{array}{c}\text { Udz } \\
7\end{array}$ & $\begin{array}{c}\text { Uluguru } \\
8\end{array}$ & $\begin{array}{c}\text { Usam } \\
9\end{array}$ & $\begin{array}{c}\text { Usam } \\
10\end{array}$ & $\begin{array}{c}\text { Usam } \\
11\end{array}$ & $\begin{array}{c}\text { Pare } \\
12\end{array}$ & $\begin{array}{c}\text { Pare } \\
13\end{array}$ & $\begin{array}{c}\text { Pare } \\
14\end{array}$ & $\begin{array}{l}\mathrm{SH} \\
15\end{array}$ & $\begin{array}{l}\text { SH } \\
16\end{array}$ & $\begin{array}{c}\text { SWH } \\
17\end{array}$ \\
\hline Crop change (millet) & & & & & & $\mathrm{x}$ & & & & & $x$ & & & & & $\mathrm{x}$ & $x$ \\
\hline Change to improved variety & $\mathrm{x}$ & & & & & & & & $x$ & $x$ & & & & & & & \\
\hline Change to improved variety (maize) & & & & & & $x$ & & & & & $x$ & & & & & $\mathrm{x}$ & \\
\hline Change to improved variety (beans) & & & & & & & & & & & & & & & & $\mathrm{x}$ & \\
\hline Change to improved variety (potatoes) & & & & & & & & & & & & & & $x$ & & & \\
\hline Change to improved variety (onions) & & & & & & & & & & & & & & & & & \\
\hline Change to improved variety (banana) & & & & & & & & & & & & & & & & $\mathrm{x}$ & \\
\hline Increased shade in coffee & & & & $\mathrm{x}$ & & & & & & & & & & & & & \\
\hline Increased farm size & & & & & & $\mathrm{x}$ & $\mathrm{x}$ & & & & $x$ & & & & & & \\
\hline Changed farm location (near stream) & & & & & & $x$ & & & & & $x$ & & $x$ & $x$ & $x$ & & \\
\hline Increased irrigation & $x$ & $\mathrm{x}$ & & & $x$ & & $x$ & $\mathrm{x}$ & $x$ & $x$ & & & $x$ & & $x$ & $x$ & \\
\hline Sow seeds earlier & & & & & & & & & & & & & & & & & \\
\hline Sow seeds later & & & & & & & & & $x$ & & & & & & & $x$ & \\
\hline Sow seeds twice (if they die) & & & & & & & & & & $x$ & & & & & & & \\
\hline Increased use soil conservation & $x$ & $x$ & & & & $x$ & & $x$ & $x$ & $x$ & $x$ & & & & & $x$ & \\
\hline Increased use fertiliser & & $\mathrm{x}$ & & & & $x$ & & & $x$ & $x$ & $\mathrm{x}$ & & & & & & \\
\hline Increased use feed (cows) & & & & & & & & & & & & & & & & & \\
\hline Diversify: sell firewood & & & & & & & & & & & & & & & & $\mathrm{x}$ & \\
\hline Diversify: NTFPs (hunting, honey) & & & & & & & & & & & & & & & & & \\
\hline Diversify: labour & $x$ & & & & & & & & & & & $x$ & & & & $x$ & \\
\hline Diversify: started rearing animals & & & & & & $x$ & & & & $\mathrm{x}$ & $x$ & & & & & $\mathrm{x}$ & \\
\hline Diversify: vegetable/fruit production & $x$ & & & & & & & & & & & & & & $\mathrm{x}$ & $x$ & \\
\hline Diversify: trading animal products & & & & & & & & & & & & & & & & & \\
\hline Diversify: small business & & & & & & & & & & & & & & & & $x$ & \\
\hline Diversify: tourism & & & & & & & & & & & & & & & & & \\
\hline Diversity: seasonal migration to cities & $\mathrm{x}$ & & & & & & & & & & & $x$ & & & & & \\
\hline
\end{tabular}


Interestingly, gender did not influence perceptions of climatic changes, impacts, or adaptive strategies. This is in contrast to other studies in African mountains such as Mount Elgon, Uganda [85], where important differences between male and female respondents were reported. The explanation for this may be related to the fact that today, the distinction in gender-based roles in Chagga and Hehe societies is starting to blur and that education and access to information in our study areas are becoming more accessible to women. On the other hand, it could be argued that lack of differences is related to the fact that we interviewed few female-headed households $(9.7 \%)$, resulting in a reporting bias (Supplementary Material B). Future work should explore the adaptive strategies of poor female-headed households in more detail, e.g., see [86].

\subsection{Other Factors Supporting or Hindering the Adoption of Adaptation Strategies}

Despite being climate change literate, most farmers in both mountains still rely on their own observations to judge the timing and quality of the coming growing season. Some farmers mentioned that the signs they used are not as accurate as they once were. These findings were also observed by $[59,87]$, who showed climate variability could undermine farmers' confidence in their existing knowledge and practices and hinder farmers' ability to plan and manage new pests.

An important factor that can support adaptation is membership in farmers organisations. Organisations help farmers access loans to, for instance, buy improved seed varieties, buy agrochemicals, irrigate, and employ soil conservation techniques, as shown in many other studies [57,88-90].

Similar to [42,90], we found that ongoing demographic shifts and out-migration to urban centres means labour availability (e.g., to maintain irrigation canals or terraces) is another growing challenge for farmers left behind in rural origins. This trend is situated amidst the larger context, where Tanzania is currently experiencing a dramatic movement in labour out of agriculture to higher-return sectors. Meanwhile, commercial farms are increasingly claiming a prominent role and competition over land and water is growing [90]. Compounding these factors is the widening inequality associated with the coronavirus pandemic. Health and economic pressures intersect with climate shocks, and farmers have been among those that have borne the brunt—struggling to sell their produce with plunged consumer demand and changing export markets in Tanzania [91].

\subsection{Limitations and Future Research Avenues}

Our study has limitations and points towards future research avenues. First, we acknowledge that the sample size of 300 households and 4 villages per site is not statistically representative of the entire population. Nevertheless, we believe that the trends observed are likely to be found in the larger population in these and other mountain regions in the Global South. Future research should consider more villages, a larger population, and more ecological and social contexts. Second, future work should sample female-headed households more exhaustively. Third, future longitudinal research could study local perceptions across different seasons and years. Nevertheless, as our study was conducted in 2020, which was a relatively wet year [92], we argue that perceptions of reduced rainfall are not necessarily related to the particular year but are more representative of a wider trend. Fourth, future research should consider the influence of other intrinsic and extrinsic factors, such as beliefs and intentions of individuals and households [93], access to market, extension services, crop insurance, infrastructure, other farming inputs, land transactions and consolidation measures, as well as agricultural policies [84].

\section{Broader Implications for Policy and Practice}

Our findings have five major implications for policy and practice.

First, climatic changes are already perceived by local communities on Mount Kilimanjaro and the Udzungwa Mountains, which agree on reports by farmers in other mountains in Tanzania and East Africa. Notably, our participants reported a larger number of changes 
and impacts. In mountain regions where complex topography and terrain causes different local climatic conditions [18], local insights based on long-term verified patterns should be used to test how models and their underlying hypotheses are built [94], particularly in meteorologically data-scarce regions or at fine geographic scales, as highlighted by other authors $[31,58,95]$. Capacity-building among national and regional meteorological departments and sustained interactions between diverse stakeholders can help increase the use of climate information while addressing issues of trust and reliability on the forecasts [96,97].

Second, local farmers utilise a range of adaptation strategies, some of which have evolved over long periods of time, and others which are in response to new emerging patterns [98]. To assess the scalability, sustainability, and replicability of adaptation strategies, each strategy should be evaluated depending on the technical, social, biophysical, infrastructural, economic, and regulatory contexts, communications, stakeholder involvement, and barriers such as financial, human, social labour, land, and access to rapid credit $[56,99,100]$. Policy interventions can build the adaptive capacity of high mountain communities by supporting social learning and farmers' ability to experiment $[96,101]$, expand their social networks, access external support for nontraditional adaptations, and internally reflect on their adaptation practices [98].

Third, despite widespread climate change literacy, farmers prefer to use personal observations over meteorological forecasts. This highlights the need to tailor forms of dissemination to local needs in terms of timing (e.g., farmers indicated a 2-day forecast was too short notice to start preparing their fields), format (e.g., cost-effective radio communication; advice given by extension workers) [80], and spatial resolution (e.g., farmers suggested forecasts were too coarse to deal with farm-level decisions) - as shown by [102] in the case of rural farmers in West Africa. There is a need to ensure credible communication procedures of forecasts [103].

Fourth, our results show differences in adaptive responses according to wealth groups. Numerous studies have documented how wealthier households generally have more options for adaptation [31]. However, overall, our findings show that the story is not so simple. There is a need to consider wealth when designing adaptation interventions within and across study sites, as some wealthier households might have fewer options than poorer households. In light of growing inequality - particularly during the coronavirus pandemicand wider transformations in Tanzanian society, policies should carefully consider how wealth from subsistence and commercial farming and mixed sector off-farm income can be reinvested in locally produced, employment-intensive goods and services to reduce inequality, secure the livelihoods current and new workers, and drive intensification [90]. Better international cooperation and faster development action is needed to limit the loss of traditional knowledge in mountain farming communities [2,104].

Fifth, previous research has shown how many well-intended national policies for adaptation have prioritised large-scale infrastructure solutions or technocentric quick fixes. Such approaches typically fail to reach mountain communities, overlook the vital importance of context, and mobilise communities' profound attachment to nature from cultivating parcels of land on mountain slopes for centuries $[27,65,105]$. To identify promising future adaptation pathways, we recommend the use of a 'science with society' participative, transdisciplinary approach [104], an iterative process that brings together actors to engage in knowledge co-production. Appreciating cultural values helps build trust between local peoples and other agencies and provides a closer understanding of differentiated climate hazard exposure, vulnerabilities, risk, and resilience [19].

Nationally, insights are relevant for realising the plans of the Southern Agricultural Corridor of Tanzania public-private partnership's vision to introduce climate-smart practices to farmers, boost agricultural productivity, food security, environmental sustainability, and reduce poverty - particularly in the Kilombero cluster, which will influence the Udzungwa Mountains [56]. Results can inform Tanzania's National Adaptation Programme of Action- which explicitly mentions Mount Kilimanjaro, the Eastern Arc and Southwestern highlands, but not the Udzungwa Mountains [106]. Internationally, results 
can inform ongoing processes to secure the resilience of Indigenous peoples living in mountains: not least of which are the Sustainable Development Goal 2 on Zero Hunger (target 2.3.2), Goal 3 on health and well-being, Goal 4 on education (target 4.5.1), and Goal 5 on gender equality and the need to 'leave no one behind'. Results also have relevance for Agenda 2063-and targets of climate-proof investments (aspiration 1.7); ensuring local people are appropriately consulted in landscape planning (aspiration 6); and that citizens are healthy, well-nourished, educated, and strong (aspiration 1.3).

\section{Conclusions}

This study shows how local communities' perceptions can be used to identify the nuances of the climatic changes and impacts already observed in mountain regions. It also illustrates how farmers are using a wide range of adaptation strategies, most of which focus on modifying farming practices and how wealth affects adaptation options. Understanding the local context is important in mountain regions [107], but some of the key considerations of the Chagga and Hehe (e.g., effects of wealth on adaptation) can help inform policy and practice in other mountains in Africa and beyond where such climate change risks are likely to be the most acute.

Supplementary Materials: The following are available online at https:/ /www.mdpi.com/article/ 10.3390/land10100999/s1.

Author Contributions: Conceptualisation, J.P.R.T., A.C.-S., and E.H.M.; Methodology, A.C.-S. and J.P.R.T.; Data gathering, F.M. and K.R.K.; Formal analysis, A.C.-S., F.M., K.R.K., and J.P.R.T.; Writingoriginal draft preparation, A.C.-S. and J.P.R.T.; Writing-review \& editing, K.R.K., A.C.-S., F.M., E.H.M., R.A.M. and J.P.R.T. Project administration and supervision, J.P.R.T., A.C.-S., and E.H.M. All authors reviewed the final draft of the manuscript. All authors have read and agreed to the published version of the manuscript.

Funding: We acknowledge funding from the UK Research and Innovation's Global Challenges Research Fund (UKRI GCRF) through the Development Corridors Partnership project (project number: ES/P011500/1). This work was also supported through the African Women in Climate Change Science Fellowship of the African Institute of Mathematical Sciences and the Next Einstein Forum, and the Climate Research for Development (CR4D) Postdoctoral Fellowship CR4D-19-21 implemented by the African Academy of Sciences (AAS) in partnership with the United Kingdom's Department for International Development (DfID) Weather and Climate Information Services for Africa (WISER) programme and the African Climate Policy Center (ACPC) of the United Nations Economic Commission for Africa (UNECA).

Institutional Review Board Statement: Ethical review and approval were received for this study by the Ethics Committee of the Department of Environment and Geography and Tanzania Commission for Science and Technology (COSTECH).

Informed Consent Statement: Informed consent was obtained from all subjects in the study.

Acknowledgments: We are deeply grateful to our study participants, who graciously shared their time, energy, and stories. We thank our field assistants and facilitators for making this research possible. Thank you to COSTECH for granting us a research permit, and local authorities from the eight villages in both Kilimanjaro and Morogoro regions.

Conflicts of Interest: The authors declare no conflict of interest.

\section{References}

1. Karagulle, D.; Frye, C.; Sayre, R.; Breyer, S.; Aniello, P.; Vaughan, R.; Wright, D. Modeling global hammond landform re-gions from 250-m elevation data. Trans. GIS. 2016, 21, 1040-1060. [CrossRef]

2. Thorn, J.P.R.; Klein, J.A.; Steger, C.; Hopping, K.A.; Capitani, C.; Tucker, C.M.; Nolin, A.W.; Reid, R.S.; Seidl, R.; Chitale, V.S.; et al. A systematic review of participatory scenario planning to envision mountain social-ecological systems futures. Ecol. Soc. 2020, 25, 1-55. [CrossRef]

3. Körner, C.; Ohsawa, M. Mountain systems. In Ecosystems and Human Well-Being. Current State and Trends; Rashid, H., Robert, S., Neville, A., Eds.; Island Press: Washington DC, USA, 2015; Volume 1, pp. 681-716. 
4. Hock, R.; Rasul, G.; Adler, C.; Cáceres, B.; Gruber, S.; Hirabayashi, Y.; Jackson, M.; Kääb, A.; Kang, S.; Kutuzov, S.; et al. High mountain areas. In IPCC Special Report on the Ocean And Cryosphere in a Changing Climate; Pörtner, H.-O., Roberts, D.C., Masson-Delmotte, V., Zhai, P., Tignor, M., Poloczanska, E., Mintenbeck, K., Alegría, A., Nicolai, M., Okem, A., et al., Eds.; IPCC-Intergovernmental Panel on Climate Change: Geneva, Switzerland, 2019; pp. 131-202.

5. Sayre, R.; Frye, C.; Karagulle, D.; Krauer, J.; Breyer, S.; Aniello, P.; Wright, D.J.; Payne, D.; Adler, C.; Warner, H.; et al. A new high-resolution map of world mountains and an online tool for visualizing and comparing characterizations of global mountain distributions. Mt. Res. Dev. 2018, 38, 240-249. [CrossRef]

6. Kohler, T.; Balsiger, J.; Rudaz, G.; Debarbieux, B.; Pratt, J.; Maselli, D. Green Economy And Institutions For Sustainable Mountain Development: From Rio 1992 to Rio 2012 and Beyond; Swiss Agency for Development and Cooperation (SDC): Bern, Switzerland, 2015

7. Lalika, M.C.S.; Meire, P.; Ngaga, Y.M.; Chang'a, L. Understanding watershed dynamics and impacts of climate change and variability in the Pangani River Basin, Tanzania. Ecohydrol. Hydrobiol. 2015, 15, 26-38. [CrossRef]

8. IUCN. Pangani River System. State of the Basin Report 2007, Tanzania; Pangani Basin Water Office: Old Moshi Rd, Tanzania; IUCN Eastern Africa Regional Office: Nairobi, Kenya, 2007.

9. Cuni-Sanchez, A.; Sullivan, M.J.P.; Platts, P.J.; Lewis, S.L.; Marchant, R.; Imani, G.; Hubau, W.; Abiem, I.; Adhikari, H.; Albrecht, T.; et al. High above-ground carbon stock of African tropical montane forests. Nature 2021, 596, 536-542, in press. [CrossRef]

10. Price, M.F.; Gratzer, G.; Duguma, L.A.; Kohler, T.; Maselli, D.; Romeo, R. (Eds.) Mountain Forests in a Changing Climate—Realizing Values, Addressing Challenges; Food and Agriculture Organization of the United Nations, FAO and Swiss Agency for Development and Cooperation, SDC: Rome, Italy, 2011.

11. Ndayizeye, G.; Imani, G.; Nkengurutse, J.; Irampagarikiye, R. Ecosystem services from mountain forests: Local communi-ties' views in Kibira National Park, Burundi. Ecosyst. Serv. 2020, 45, 101171. [CrossRef]

12. Cuni-Sanchez, A.; Imani, G.; Bulonvu, F.; Batumike, R.; Baruka, G.; Burgess, N.D.; Klein, J.A.; Marchant, R. Social perceptions of forest ecosystem services in the Democratic Republic of Congo. Hum. Ecol. 2019, 47, 839-853. [CrossRef]

13. Shabalala, P. Perspectives on the Role Of Cultural Heritage Tourism In Community Development in South Africa: A study of Mapungubwe World Heritage Site in Limpopo Province. Ph.D. Thesis, The University of Witwatersrand School of Geography, Archaeology \& Environmental Studies, Braamfontein, Johannesburg, October 2020.

14. Gerrard, J. Mountain Environments: An Examination of the Physical Geography of Mountains; MIT Press: Cambridge, MA, USA; Belhaven Press: London, UK, 1990. [CrossRef]

15. Platts, P.J.; Burgess, N.D.; Gereau, R.E.; Lovett, J.C.; Marshall, A.R.; McClean, C.J.; Pellikka, P.K.; Swetnam, R.; Marchant, R. Delimiting tropical mountain ecoregions for conservation. Environ. Conserv. 2011, 38, 312-324. [CrossRef]

16. Mountain Research Initiative EDW Working Group; Pepin, N.; Bradley, R.S.; Diaz, H.F.; Baraer, M.; Caceres, E.B.; Forsythe, N.D.; Fowler, H.; Greenwood, G.; Hashmi, M.Z.; et al. Elevation-dependent warming in mountain regions of the world. Nat. Clim. Chang. 2015, 5, 424-430. [CrossRef]

17. Los, S.O.; Street-Perrott, F.A.; Loader, N.J.; Froyd, C.A.; Cuní-Sanchez, A.; Marchant, R.A. Sensitivity of a tropical montane cloud forest to climate change, present, past and future: Mt. Marsabit, N. Kenya. Quat. Sci. Rev. 2019, 218, 34-48. [CrossRef]

18. Platts, P.J.; Omeny, P.A.; Marchant, R. AFRICLIM: High-resolution climate projections for ecological applications in Africa. Afr. J. Ecol. 2014, 53, 103-108. [CrossRef]

19. IPCC. Global warming of $1.5^{\circ} \mathrm{C}$. In An IPCC Special Report On The Impacts Of Global Warming Of $1.5^{\circ} \mathrm{C}$ Above Pre-Industrial Levels And Related Global Greenhouse Gas Emission Pathways, In The Context Of Strengthening The Global Response To The Threat Of Climate Change, Sustainable Development, And Efforts To Eradicate Poverty; Masson-Delmotte, V., Zhai, P., Pörtner, H.-O., Roberts, D., Skea, J., Shukla, P.R., Pirani, A., Moufouma-Okia, W., Péan, C., Pidcock, R., et al., Eds.; IPCC: Geneva, Switzerland, 2018; in press.

20. Kangalawe, R.Y.; Liwenga, E.T. Livelihoods in the wetlands of Kilombero Valley in Tanzania: Opportunities and challenges to integrated water resource management. Phys. Chem. Earth Parts A/B/C 2005, 30, 968-975. [CrossRef]

21. Liwenga, E. Food insecurity and coping strategies in semi-arid areas: The case of Mvumi in central Tanzania. Ph.D. Thesis, Department of Human Geography, Stockholm University, Stockholm, Sweden, March 2013.

22. Hunt, C.A.; Gorenflo, L.J. Tourism development in a biodiversity hotspot. Ann. Tour. Res. 2019, 76, 320-322. [CrossRef]

23. Nielsen, M.R. Importance, cause and effect of bushmeat hunting in the Udzungwa Mountains, Tanzania: Implications for community based wildlife management. Biol. Conserv. 2006, 128, 509-516. [CrossRef]

24. Nielsen, M.R.; Treue, T. Hunting for the benefits of joint forest management in the Eastern Afromontane biodiversity hotspot: Effects on bushmeat hunters and wildlife in the Udzungwa Mountains. World Dev. 2012, 40, 1224-1239. [CrossRef]

25. Ceccarelli, F.S.; Menegon, M.; Tolley, K.A.; Tilbury, C.R.; Gower, D.J.; Laserna, M.H.; Kasahun, R.; Rodriguez-Prieto, A.; Hagmann, R.; Loader, S.P. Evolutionary relationships, species delimitation and biogeography of Eastern Afromontane horned chameleons (Chamaeleonidae: Trioceros). Mol. Phylogenet. Evol. 2014, 80, 125-136. [CrossRef]

26. Brockhaus, M.; Djoudi, H.; Locatelli, B. Envisioning the future and learning from the past: Adapting to a changing environment in northern Mali. Environ. Sci. Policy. 2012, 25, 94-106. [CrossRef]

27. Sébastien, L. The Chagga people and environmental changes on Mount Kilimanjaro: Lessons to learn. Clim. Dev. 2010, 2, 364-377. [CrossRef]

28. Kangalawe, R.Y.M. Climate change impacts on water resource management and community livelihoods in the southern highlands of Tanzania. Clim. Dev. 2017, 9, 191-201. [CrossRef] 
29. Klein, R.A.; Ratliff, K.A.; Vianello, M.; Adams, R.B., Jr.; Bernstein, M.J.; Bocian, K. Investigating variation in replicabil-ity a "many labs" replication project. Soc. Psychol. 2014, 45, 142-152. [CrossRef]

30. Reyes-García, V.; Fernández-Ilamazares, Á.; Guèze, M.; Garcés, A.; Mallo, M.; Vilagómez, M.; Vilaseca, M. Local indicators of climate change: The potential contribution of local knowledge to climate research. Wiley Interdiscip. Rev. Clim. Chang. 2016, 7, 109-124. [CrossRef] [PubMed]

31. Savo, V.; Morton, C.; Lepofsky, D. Impacts of climate change for coastal fishers and implications for fisheries. Fish Fish. 2017, 18, 877-889. [CrossRef]

32. Thorn, J.; Thornton, T.F.; Helfgott, A. Autonomous adaptation to global environmental change in periurban settlements: Evidence of a growing culture of innovation and revitalisation in Mathare Valley Slums, Nairobi. Glob. Environ. Chang. 2015, 31, 121-131. [CrossRef]

33. Seddon, N.; Chausson, A.; Berry, P.; Girardin, C.A.J.; Smith, A.; Turner, B. Understanding the value and limits of nature-based solutions to climate change and other global challenges. Philos. Trans. R. Soc. B Biol. Sci. 2020, 375, 20190120. [CrossRef] [PubMed]

34. Campbell, J.Y. No Sustainable Development without Indigenous Peoples. International Institute for Sustainable Development. 2019, pp. 1-3. Available online: https://sdg.iisd.org/commentary/guest-articles/no-sustainable-development-withoutindigenous-peoples/ (accessed on 22 May 2021).

35. Naess, L.O. The role of local knowledge in adaptation to climate change. Earth Syst. Dynam. 2013, 4, 99-106. [CrossRef]

36. Cuni-Sanchez, A.; Senghor, A.; Ngute, K.; Sonké, B.; Nsanyi, M.; Burgess, N.D.; Klein, J.A.; Marchant, R. The importance of livelihood strategy and ethnicity in forest ecosystem services' perceptions by local communities in north-western Cameroon. Ecosyst. Serv. 2019, 40, 101000. [CrossRef]

37. Petzold, J.; Andrews, N.; Ford, J.D.; Hedemann, C.; Postigo, J.C. Indigenous knowledge on climate change adaptation: A global evidence map of academic literature. Environ. Res. Lett. 2020, 15, 113007. [CrossRef]

38. Burkett, V.R.; Suarez, A.G.; Bindi, M.; Conde, C.; Mukerji, R.; Prather, M.J.; St Clair, A.; Yohe, G.W. Point of departure. In Climate Change 2014: Impacts, Adaptation, and Vulnerability. Part A: Global and Sectoral Aspects. Contribution of Working Group II to the Fifth Assessment Report of the Intergovernmental Panel on Climate Change; Field, C.B., Barros, V.R., Dokken, D.J., Mach, K.J., Mastrandrea, M.D., Bilir, T.E., Chatterjee, M., Ebi, K.L., Estrada, Y.O., Genova, R.C., et al., Eds.; Cambridge University Press: Cambridge, UK; New York, NY, USA, 2014; pp. 169-179.

39. Ford, J.D.; Cameron, L.; Rubis, J.; Maillet, M.; Nakashima, D.; Willox, A.C.; Pearce, T. Including indigenous knowledge and experience in IPCC assessment reports. Nat. Clim. Chang. 2016, 6, 349-353. [CrossRef]

40. Shukla, R.; Agarwal, A.; Sachdeva, K.; Kurths, J. Climate change perception: An analysis of climate change and risk perceptions among farmer types of Indian Western Himalayas. Clim. Chang. 2019, 152, 103-119. [CrossRef]

41. Singh, R.K.; Zander, K.K.; Kumar, S.; Singh, A.; Sheoran, P.; Kumar, A.; Hussain, S.; Riba, T.; Rallen, O.; Lego, Y.; et al. Perceptions of climate variability and livelihood adaptations relating to gender and wealth among the Adi community of the Eastern Indian Himalayas. Appl. Geogr. 2017, 86, 41-52. [CrossRef]

42. Nyasimi, M.; Kimeli, P.; Sayula, G.; Radeny, M.; Kinyangi, J.; Mungai, C. Adoption and dissemination pathways for climate-smart agriculture technologies and practices for climate-resilient livelihoods in Lushoto, Northeast Tanzania. Climate 2017, 5, 63. [CrossRef]

43. Kangalawe, R.; Mwakalila, S.; Masolwa, P. Climate change impacts, local knowledge and coping strategies in the Great Ruaha River. Nat. Resour. 2011, 212-223. [CrossRef]

44. Hemp, C.; Hemp, A.; Dettner, K.; Bayreuth, D.; Hempuni-bayreuthde, A. Canthariphilous insects in East Africa. J. East. Afr. Nat. Hist. 1999, 15, 1-15. [CrossRef]

45. Schumacher, B.L. Farmer Perceptions of Climate Change and Variability in Villages Adjacent to the Udzungwa Mountains National Park, Tanzania. Master's Thesis, University of California, Los Angeles, CA, USA, 2018.

46. Berman, R.J.; Quinn, C.H.; Paavola, J. Identifying drivers of household coping strategies to multiple climatic hazards in Western Uganda: Implications for adapting to future climate change. Clim. Dev. 2015, 7, 71-84. [CrossRef]

47. Salerno, J.; Diem, J.E.; Konecky, B.L.; Hartter, J. Recent intensification of the seasonal rainfall cycle in equatorial Africa revealed by farmer perceptions, satellite-based estimates, and ground-based station measurements. Clim. Chang. 2019, 153, 123-139. [CrossRef]

48. Francis, M.; Kraybill, D. Climate change and the future of mountain farming on Mt. Kilimanjaro. Fut. Mt. Agric. 2013, 73-88. [CrossRef]

49. Hemp, A. The banana forests of Kilimanjaro: Biodiversity and conservation of the Chagga homegardens. Biodivers. Conserv. 2006, 15, 1193-1217. [CrossRef]

50. Mbonile, M.J. Migration and intensification of water conflicts in the Pangani Basin, Tanzania. Habitat Int. 2005, 29 , 41-67. [CrossRef]

51. National Bureau of Statistics. Population and Housing Census: Population Distribution; Government of the United Republic of Tanzania: Dar es Salaam, Tanzania, 2012.

52. Salinitro, M.; Vicentini, R.; Bonomi, C.; Tassoni, A. Traditional knowledge on wild and cultivated plants in the Kilombero Valley (Morogoro Region, Tanzania). J. Ethnobiol. Ethnomed. 2017, 13, 1-14. [CrossRef]

53. United Republic of Tanzania. Fifth National Report on the Implementation of the Convention on Biological Diversity; Vice President Office of the Division of Environment of the United Republic of Tanzania: Dodoma, Tanzania, 2014. 
54. Spencer, P.; Palmer, V.; Jilek-Aall, L. Nodding syndrome: Origins and natural history of a longstanding epileptic disorder in sub-Saharan Africa. Afr. Health Sci. 2013, 13, 176-182. [CrossRef]

55. Howell, K.M.; Burgess, N.D.; Butynski, T.M.; Cordeiro, N.J.; Doggart, N.H.; Fjeldsa, J.; Kilahama, F.; Loader, S.; Lovett, J.; Mbilinyi, B.; et al. The biological importance of the Eastern Arc Mountains of Tanzania and Kenya. Biol. Conserv. 2006, 4, $209-231$. [CrossRef]

56. Rodríguez, L.G.; Hogarth, N.; Zhou, W.; Xie, C.; Zhang, K.; Putzel, L.; Rodríguez, L.G.; Hogarth, N.; Zhou, W.; Xie, C.; et al. China's conversion of cropland to forest program: A systematic review of the environmental and socioeconomic effects. Environ. Evid. 2016, 5, 21. [CrossRef]

57. Córdova, A. Measuring Relative Wealth using Household Asset Indicators and Principal Component Analysis (PCA); Amer Barome "Insights" Series; LAPOP: Nashville, TN, USA, 2009.

58. Sanchez, A.C.; Pfeifer, M.; Marchant, R.; Pompeu, P.V. Harvesting fodder trees in montane forests in Kenya: Species, tech-niques used and impacts. New For. 2018, 49, 511-528. [CrossRef]

59. Wagner, S.; Jassogne, L.; Price, E.; Jones, M.; Preziosi, R. Impact of climate change on the production of coffea arabica at Mt. Kilimanjaro, Tanzania. Agriculture 2021, 11, 53. [CrossRef]

60. Velempini, K.; Smucker, T.A.; Clem, K.R. Community-based adaptation to climate variability and change: Mapping and assessment of water resource management challenges in the North Pare highlands, Tanzania. Afr. Geogr. Rev. 2016, 6812, 1-22. [CrossRef]

61. Kassian, L.M.; Tenywa, M.; Liwenga, E.T.; Dyer, K.W.; Bamutaze, Y. Implications of climate change and variability on stream flow in Iringa region, Tanzania. J. Water Clim. Chang. 2017, 8, 336-347. [CrossRef]

62. Mgumia, A.H.; Mattee, A.Z.; Kundi, B.A.T. Contribution of innovation intermediaries in agricultural innovation: The case of agricultural R\&D in Tanzania. Afr. J. Sci. Technol. Innov. Dev. 2015, 7, 151-160. [CrossRef]

63. Mwakalila, S. Climate variability, impacts and adaptation strategies: The Case of Mbeya and Makete Districts in Great Ruaha Catchment in Tanzania. J. Water Resour. Prot. 2014, 6, 43-48. [CrossRef]

64. Pauline, N.M.; Grab, S. Whose knowledge matters in climate change adaptation? Perceived and measured rainfall trends during the last half century in south-western Tanzania. Singap. J. Trop. Geogr. 2018, 39, 266-280. [CrossRef]

65. Hamilton, A. Vegetation, climate and soil: Altitudinal Relationships on the East Usambara Mountains, Tanzania. J. East. Afr. Nat. Hist. 1998, 87, 85-89. [CrossRef]

66. Reyes-Garcíaa, V.; Fernández-Llamazaresc, Á.; McElweed, P.; Molnáre, Z.; Öllerere, K.; Wilsong, S.J.; Brondizio, E.S. The contributions of indigenous peoples and local communities to ecological restoration. Restor. Ecol. 2018, 27, 3-8. [CrossRef]

67. Hartter, J.; Stampone, M.D.; Ryan, S.J.; Kirner, K.; Chapman, C.A.; Goldman, A. Patterns and perceptions of climate change in a biodiversity conservation hotspot. PLOS ONE 2012, 7, e32408. [CrossRef] [PubMed]

68. Hemp, A. Climate change-driven forest fires marginalize the impact of ice cap wasting on Kilimanjaro. Glob. Chang. Biol. 2005, 11, 1013-1023. [CrossRef]

69. Calatayud, P.A.; Njuguna, E.; Mwalusepo, S.; Gathara, M.; Okuku, G.; Kibe, A.; Musyoka, B.; Williamson, D.; Ong'Amo, G.; Juma G.; et al. Can climate-driven change influence silicon assimilation by cereals and hence the distribution of lepidop-teran stem borers in East Africa? Agric. Ecosyst. Environ. 2016, 224, 95-103. [CrossRef]

70. Agrawala, S.; Moehner, A.; Hemp, A.; van Aalst, M.; Hitz, S.; Smith, J.; Meena, H.; Mwakifwamba, S.M.; Hyera, T.; Mwaipopo, O.U. Development and Climate Change in Tanzania: A Focus on Mount Kilimanjaro; Organisation for Economic Cooperation and Development: Paris, France, 2003.

71. Garibaldi, A.; Turner, N. Cultural keystone species: Implications for ecological conservation and restoration. Ecol. Soc. 2004, 9, 1. [CrossRef]

72. Mwakaje, A.G. The impact of climate change and variability on agro-pastoralists' economy in Tanzania. Environ. Econ. 2013, 4, 30-38.

73. Balama, C.; Augustino, S.; Eriksen, S.; Makonda, F.B.S. Forest adjacent households' voices on their perceptions and adapta-tion strategies to climate change in Kilombero District, Tanzania. SpringerPlus 2016, 5, 792. [CrossRef] [PubMed]

74. Fernández, C.; Vega, J.A.; Fonturbel, T.; Pérez-Gorostiaga, P.; Jiménez, E.; Madrigal, J. Effects of wildfire, salvage logging and slash. Land Degrad. Dev. 2007, 607, 591-607. [CrossRef]

75. Talukder, B.; van Loon, G.W.; Hipel, K.W.; Chiotha, S.; Orbinski, J. Health impacts of climate change on smallholder farmers. One Health 2021, 13, 100258. [CrossRef] [PubMed]

76. Paavola, J. Livelihoods, vulnerability and adaptation to climate change in Morogoro, Tanzania. Environ. Sci. Policy. 2008, 11, 642-654. [CrossRef]

77. Ahrends, A.; Burgess, N.D.; Milledge, S.A.H.; Bulling, M.T.; Fisher, B.; Smart, J.C.R.; Clarke, G.P.; Mhoro, B.E.; Lewis, S. Predictable waves of sequential forest degradation and biodiversity loss spreading from an African city. Proc. Natl. Acad. Sci. USA 2010, 107, 14556-14561. [CrossRef]

78. Eshetu, G.; Johansson, T.; Garedew, W.; Yisahak, T. Determinants of smallholder farmers' adaptation options to climate change in a coffee-based farming system of Southwest Ethiopia. Clim. Dev. 2021, 13, 318-325. [CrossRef]

79. Mombo, F.; Speelman, S.; Huylenbroeck, G.; Van Hella, J.; Moe, S. Ratification of the Ramsar convention and sustainable wetlands management: Situation analysis of the Kilombero Valley wetlands in Tanzania. J. Agric. Ext. Rural. Dev. 2011, 3, $153-164$. 
80. Mastrorillo, M.; Licker, R.; Bohra-Mishra, P.; Fagiolo, G.; Estes, L.D.; Oppenheimer, M. The influence of climate variability on internal migration flows in South Africa. Glob. Environ. Chang. 2016, 39, 155-169. [CrossRef]

81. Hummel, D. Climate change, land degradation and migration in Mali and Senegal-Some policy implications. Migr. Dev. 2016, 5, 211-233. [CrossRef]

82. Call, M.; Gray, C. Climate anomalies, land degradation, and rural out-migration in Uganda. Popul. Environ. 2020, 41, 507-528. [CrossRef] [PubMed]

83. Skjeflo, S. Measuring household vulnerability to climate change- why markets matter. Glob. Environ. Chang. 2013, 23, 1694-1701. [CrossRef]

84. Msalilwa, U.; Balama, C.; Fixation, N. The role of on-farm trees as an adaptation strategy to climate change effects around Mkingu Nature Forest Reserve in the Eastern Arc Mountains. Tanzan. J. For. Nat. Conserv. 2017, 86, 1.

85. Bomuhangi, A.; Nabanoga, G.; Namaalwa, J.J.; Jacobson, M.G.; Abwoli, B. Local communities' perceptions of climate variability in the Mt. Elgon region, eastern Uganda. Cogent Environ. Sci. 2016, 2, 1-16. [CrossRef]

86. Mersha, A.A.; Van Laerhoven, F. A gender approach to understanding the differentiated impact of barriers to adaptation: Responses to climate change in rural Ethiopia. Reg. Environ. Chang. 2016, 16, 1701-1713. [CrossRef]

87. West, C.T.; Roncoli, C.; Ouattara, F. Local perceptions and regional climate trends on the Central Plateau of Burkina Faso. Land Degrad. Dev. 2008, 304, 289-304. [CrossRef]

88. Mwalusepo, S.; Massawe, E.S.; Johansson, T. Spatially continuous dataset at local scale of Taita Hills in Kenya and Mount Kilimanjaro in Tanzania. Data Brief. 2016, 8, 1115-1119. [CrossRef]

89. Mwalusepo, S.; Tonnang, H.E.Z.; Massawe, E.S.; Okuku, G.O.; Khadioli, N.; Johansson, T.; Calatayud, P.-A.; Le Ru, B.P. Predicting the impact of temperature change on the future distribution of maize stem borers and their natural enemies along East African mountain gradients using phenology models. PLoS ONE 2015, 10, 1-23. [CrossRef]

90. Wineman, A.; Jayne, T.S.; Isinika Modamba, E.; Kray, H. The changing face of agriculture in Tanzania: Indicators of transformation. Dev. Policy Rev. 2020, 38, 685-709. [CrossRef]

91. Win, T.L.; O'Brien, C. Hungry for Change: Faulty Food Systems Laid Bare by COVID-19 and Climate Crises. Thomson Reuter Foundation News. 2021. Available online: https:/ /news.trust.org/item/20201227080204-3652n/ (accessed on 10 June 2021).

92. International Federation of Red Cross and Crescent Societies. DREF Operation Final Report; UNCHR: Geneva, Switzerland, 2020.

93. Kuivanen, K.S.; Alvarez, S.; Michalscheck, M.; Adjei-Nsiah, S.; Descheemaeker, K.; Mellon-Bedi, S.; Groot, J. Characterising the diversity of smallholder farming systems and their constraints and opportunities for innovation: A case study from the Northern Region, Ghana. NJAS Wagening. J. Life Sci. 2016, 78, 153-166. [CrossRef]

94. UNESCO. Report of the UNESCO Expert Meeting on Indigenous Knowledge and Climate Change in Africa. 2018. Available online: http:/ / creativecommons.org/licenses/by-sa/3.0/igo/ (accessed on 20 June 2021).

95. Thorn, J.P.R. Adaptation "from below" to changes in species distribution, habitat and climate in agro-ecosystems in the Terai Plains of Nepal. Ambio 2019, 48, 1482-1497. [CrossRef]

96. Plummer, R.; Armitage, D. Integrating perspectives on adaptive capacity and environmental governance. Environ. Res. Lett. 2010, 1,1-19. [CrossRef]

97. Bryan, E.; Deressa, T.T.; Gbetibouo, G.A.; Ringler, C. Adaptation to climate change in Ethiopia and South Africa: Options and constraints. Environ. Sci. Policy 2009, 12, 413-426. [CrossRef]

98. Boillat, S.; Berkes, F. Perception and interpretation of climate change among Quechua farmers of Bolivia: Indigenous Knowledge as a Resource for Adaptive. Ecol. Soc. 2013, 18, 18900672. [CrossRef]

99. Abraham, T.W.; Fonta, W.M. Climate change and financing adaptation by farmers in northern Nigeria. Financ. Innov. 2018, 4, 11. [CrossRef]

100. Pickson, R.B.; He, G. Smallholder farmers' perceptions, adaptation constraints, and determinants of adaptive capacity to climate change in Chengdu. SAGE Open 2021, 11, 21582440211032638. [CrossRef]

101. Hansen, J.W.; Vaughan, C.; Kagabo, D.M.; Dinku, T.; Carr, E.R.; Körner, J.; Zougmoré, R.B. Climate services can support African farmers' context-specific adaptation needs at scale. Front. Sustain. Food Syst. 2019, 3, 1-16. [CrossRef]

102. Adejuwon, J.O.; Odekunle, T.O.; Omotayo, O. Extended-Range Weather Forecasting in Sub-Saharan West Africa: Assessing a Potential Tool For Adapting Food Production To Climate Variability And Climate. 2007, pp. 1-43. Available online: http: / / aiaccproject.org/working_papers/WorkingPapers/AIACC_WP46_Adejuwon.pdf (accessed on 10 May 2021).

103. Murphy, S.J.; Washington, R.; Downing, T.E.; Martin, R.V.; Ziervogel, G.; Preston, A.; Todd, M.; Butterfield, R.; Briden, J. Seasonal forecasting for climate hazards: Prospects and responses. Nat. Hazards 2001, 23, 171-196. [CrossRef]

104. Steger, C.; Klein, J.A.; Reid, R.S.; Lavorel, S.; Tucker, C.; Hopping, K.A.; Marchant, R.; Teel, T.; Cuni-Sanchez, A.; Dorji, T.; et al. Science with society: Evidence-based guidance for best practices in environmental transdisciplinary work. Glob. Environ. Chang. 2021, 68, 102240. [CrossRef]

105. Smucker, T.A.; Wangui, E.E. Gendered knowledge and adaptive practices: Differentiation and change in Mwanga District, Tanzania. Ambio 2016, 45, 276-286. [CrossRef]

106. United Republic of Tanzania. National Adaptation Programme of Action (NAPA). 2007. Available online: http://unfccc.int/ resource/docs/napa/tza01.pdf (accessed on 10 May 2021).

107. Klein, J.A.; Tucker, C.M.; Nolin, A.W.; Hopping, K.A.; Reid, R.S.; Steger, C. Catalyzing transformations to sustainability in the world's mountains. Earth's Future 2019, 7, 547-557. [CrossRef] 